\title{
Assessing Architecture-and-Landscape Integration as a Basis for Evaluating the Impact of Construction Projects on the Cultural Landscape of Tourist Seaside Resorts
}

\author{
Wojciech Bal (D) and Magdalena Czalczynska-Podolska *(D)
}

Citation: Bal, W.;

Czalczynska-Podolska, M. Assessing Architecture-and-Landscape Integration as a Basis for Evaluating the Impact of Construction Projects on the Cultural Landscape of Tourist Seaside Resorts. Land 2021, 10, 17 https://doi.org/10.3390/land10010017
Department of Contemporary Architecture, Design Theory and Methodology, West Pomeranian University of Technology in Szczecin, 70-310 Szczecin, Poland; wojciech.bal@zut.edu.pl

* Correspondence: magdalena.czalczynska-podolska@zut.edu.pl
Received: 30 November 2020 Accepted: 24 December 2020 Published: 28 December 2020

Publisher's Note: MDPI stays neutral with regard to jurisdictional clai$\mathrm{ms}$ in published maps and institutional affiliations.

Copyright: (C) 2020 by the authors. Licensee MDPI, Basel, Switzerland. This article is an open access article distributed under the terms and conditions of the Creative Commons Attribution (CC BY) license (https:// creativecommons.org/licenses/by/ $4.0 /)$.

\begin{abstract}
The coastline of Western Pomerania has natural and cultural assets that have promoted the development of tourism, but also require additional measures to ensure the traditional features and characteristics are protected. This is to ensure that new developments conform to a more uniform set of spatial structures which are in line with the original culture. Today, seaside resorts are characterized by a rapid increase in development with a clear trend towards non-physiognomic architectural forms which continually expand and encroach on land closer to the coastline. This results in a blurring of the original concepts that characterized the founding seaside resort. This study evaluates 11 development projects (including a range of hotels, luxury residential buildings and hotel suites) built in 2009-2020 in the coastal area of Western Pomerania. An assessment of architecture-and-landscape integration for each development project was made, using four groups of evaluation criteria: aesthetic, socio-cultural, functional and locational factors. The study methodology included a historical and interpretative study (iconology, iconography, historiography) and an examination of architecture-and-landscape integration using a pre-prepared evaluation form. Each criterion was first assessed using both field surveys and desk research (including the analysis of construction plans and developer materials), and then compared with the original, traditional qualities of the town. This study demonstrates that it is possible to clearly identify the potential negative impact of tourism development on the cultural landscape of seaside resorts, and provides recommendations for future shaping, management and conservation of the landscape.
\end{abstract}

Keywords: architecture-and-landscape integration; cultural landscape; seaside resorts; tourism development

\section{Introduction}

In view of the progressive landscape degradation occurring in many regions around the world as a result of the intensive development of tourism, it is necessary to continuously monitor this process and develop effective ways to conserve the natural/traditional landscape and promote a sustainable approach to spatial management and tourism. In Western Pomerania, the Baltic Sea coastal area is distinguished by its superior natural and cultural resources. This $185 \mathrm{~km}$ long coastal strip is characterized by a wealth of fauna and flora, with a cliffed coast and sandy beaches, which are separated from the mainland by dunes which support unique plants. Furthermore, according to the National Heritage Board of Poland (NID) data, there are 3139 objects entered in the register of immovable historical monuments in the West Pomeranian Province. Many of these features are architectural, related to the development of the recreational and spa facilities in the second half of the nineteenth century, which have shaped the unique cultural landscape of the region. Given the natural and cultural assets of this region, these areas are particularly attractive for tourism-driven development projects, with a significant number of planning decisions being made in order to promote the tourism-related economy but which also often result 
in landscape degradation. Therefore, additional consideration for conserving traditional values is required, whilst also supporting the economic development of the region.

The modern seaside tourist resorts of Western Pomerania have developed from former fishing villages or small summer resorts. Before World War II, these localities conformed to regional and national traditional architectures with shared cultural roots. They all contained distinctive and similar features, including a promenade, a pier, blocks of changing rooms, family bathing beaches, a spa park and a band shell; the form and usage of guesthouses and hotels reflected the concept of a resort as an recreational drawing room for the upper class [1,2]. More recently, seaside resorts have experienced a heavy increase in developments which have a more modern architecture with fewer regional features, and which have expanded further toward the coastline creating areas of congested development [1]. Overall, this has resulted in a blurring of the traditional founding ideas that were central to the original seaside resorts.

Therefore, it is imperative to analyze and evaluate the growth of tourism and the impact of the development along the coast on the natural and cultural landscape. Using a range of criteria to assess architecture-and-landscape integration [3] can be a useful tool in evaluating planned and completed development projects related to tourism in the region. The integration of architecture and landscape as part of the rebuilding and conservation of cultural landscape increases local awareness of their relationship with the surrounding environment, which will promote sustainable development and contribute to suitable planning and management of the region.

This study aims to evaluate selected construction projects (completed in recent years in the coastal strip of Western Pomerania) in the context of landscape transformation and the growth of tourism in regional seaside resorts. The analysis included 11 architectural and urban planning projects which were completed in 2009-2020, or which were in the final stages of the investment process (due for completion in 2021). These development projects included hotels, luxury residential buildings and hotel suites, which have been constructed in response to the intensive expansion of tourism in seaside resorts. The research is based on the original concept of architecture-and-landscape integration, developed by the authors of the article. Similar studies with the use of the criteria of integration of architecture and landscape for investment evaluation have not been conducted so far.

\section{Background and Context}

\subsection{Previous Studies on the Impact of Tourism on the Landscape of Seaside Resorts}

Tourism is a force that both creates new spaces and transforms existing settlements [4]. The cultural landscape of a given region is determined by a combination of local, national and continental heritage (in this case European) [5]. Unfortunately, many traditional landscapes are vulnerable to transformation as a result of increasing tourism, which affects the environment, economy, society and aesthetics [6]. Destinations that feature assets relating to both the land and the water are particularly sensitive; hence the development of tourism and leisure has a significant impact on the changes in the cultural and natural landscape of the coastline. Additionally, changes in the cultural landscape and development of seaside resorts are enhanced as tourism causes additional broader changes in social and demographic factors [7].

Analyses on the impact of tourism usually consider three factors: environmental, sociocultural or economic [8]. These studies attempt to take a multi-faceted approach to search for links between tourism, the economy, the environment and the local community, in order to understand the key relationships between these factors that attract tourists [9-15]. According to Urry [16], tourists look for unique, unusual and untamed places or landscapes. Cultural heritage, architecture, vegetation and sensory experiences (i.e., flavors, scents and sounds) are also identified as important for tourists [17]. The uniqueness and authenticity of a place is also an attractive asset [18]. However, the increased interest in such places leads to changes in their character. "There is a characteristic transformation of places where the local and the global are linked together through tourism" [19] (p. 384). There is a need to provide 
a large number of tourists with lodging, and this stimulates the growth of hotel and luxury residential developments. Although the growth of condominium-style accommodation may initially be the main factor to attract a large number of tourists to a town, it may prevent its successful "rejuvenation" in the future [20]. In some places, there is the effect of a second-home landscape, which has a physical, empirical and cultural impact [21].

In seaside landscapes, which are particularly vulnerable to the adverse effects of tourism, landscape deterioration is often caused by urbanization and development which degrades natural and cultural resources [22,23]. In towns where tourism takes on a mass character, a progressive westernization or "McDonaldization" of the landscape is observed [24], where non-physiognomic forms of building emerge [25]. Development is often characterized by construction of large hotel buildings and suites for rent, whose size and form are often dramatically different from local construction traditions and disturbs the cultural continuity in the town [1]. Counterintuitively, this could lead to the destruction of the traditional landscapes that attracted tourists in the first place [26]. The expansion and intensification of land development also often destroys unique natural assets. For example, the native vegetation of coastal areas is reduced and replaced by agricultural land and residential, recreational, commercial or industrial buildings [27]. These changes affect not only how the tourists perceive the town, but also how the local community understands and experiences the landscape [28]. This is because the tourist landscapes exist at the border of history and politics, where the social relations and the perception of culture meet [29].

The solution for this could be to expand tourism through use of sustainable development and management practices, which take into account both the needs of tourists and local residents whilst facilitating future development opportunities in these areas [30,31]. Sustainable tourism seeks to ensure a suitable balance between the economic, environmental and social aspects of tourism development in order to safeguard its long-term sustainability [32]. In line with this, long-term monitoring and evaluation of current and ongoing changes occurring as a result of expanding tourism is essential, including analysis of both the conditions set for already issued planning permissions and the number of planning permissions accepted.

The analysis of the cultural landscape appears to be a useful tool for evaluating the multi-faceted impact of tourism on the development of towns, showing the societal approach to spatial management. Developing appropriate methods by which to assess the landscape is critical to ensure proper conservation and shaping targets are set. These targets include suitable activities that could create conditions for sustainable development and spatial order [3], and which enable tourism to develop whilst protecting the natural/traditional assets that attract tourists.

\subsection{Evaluation of the Landscape in Existing Studies}

The methods previously used to evaluate the landscape to date can be divided into methods that evaluate individual natural features of the environment (to determine natural values), methods that evaluate aesthetic value of the landscape associated with its composition, and methods that analyze the usefulness of the landscape for a specific purpose (e.g., recreation, spatial planning and sozology). Previous evaluations of cultural landscapes use methods based on subjective evaluation of the observer's visual experience (spatial order), such as the Scenic Beauty Estimation (SBE) method, which is based on the intensity of observer's experience [33]. Alternatively, the Visual Resource Management (VRM) system [34] is used to find the level of contrast between the conducted investment and the existing landscape, and in the evaluation of its visual resources while the Experience Curve Method is a graphical record of observer's emotions related to the aesthetics of surroundings occurring over time [35]. Landscape visual quality, which is defined as the aesthetical perfection of the landscape [36], is the primary component of the natural and cultural environment, which in turn has an influence on the overall quality of the tourism/leisure experience [37]. Therefore, the Visual Landscape Quality Assessment is appropriately used 
in analyses conducted to study various tourist regions. These assessments are based on expert opinions, user perception or a combination of both expert and user opinion [38]. The participation of users in visual landscape quality analyses increases the objectivity of results [39] and contributes to the validity of the study [40,41].

The selection of appropriate evaluation criteria is essential in such studies. Keleş E., Atik D. and Bayrak G. [42] stated that visual quality assessment is based on 14 parameters (coherence, imageability, historicity, sense of place, visual impressiveness, stewardship, complexity, legibility, originality, accessibility, naturalness, security, inconsistency and city identity), which they used to evaluate places with significant historical values. Alternatively, Myga-Piatek U. [43] proposed that cultural landscape should be evaluated using the following criteria: ancientness, historicity, aesthetic value, genuine substance, harmony, uniqueness, content, emotional and practical value. In another study, B. Żarska [44] proposed the best method to assess the cultural landscape should use criteria derived from how monuments are preserved. This study suggested that an evaluation of the cultural features of local and supra-local importance should be made, such as monuments harmonizing with their surroundings and the existence of valuable cultural elements.

A conservation-oriented evaluation of cultural landscape provides a basis for the preservation of historical architectural and landscape ensembles but appears to be somewhat less useful in analyzing new projects and the conditions of towns where the growth of tourism is not based mainly on historical assets. This is mainly due to the absence of studies that assess the links between tourism and landscape [28]. Therefore, the different aspects of the landscape (including tourism) require individually appropriate methods for planning, managing and evaluation. An alternative method is the Seascape Character Assessment (SCA) which can evaluate, characterize, map and describe the character of the coastal landscape [45]. There is a need to develop new cultural landscape evaluation methods that are more appropriate for areas with many construction projects already under construction, which take into account future seaside development plans and strategies, and which are relevant to the specific nature of the study region.

\section{Materials and Methods}

The evaluation of the selected development projects in this study was based on the authors' definition of architecture-and-landscape integration and used a multi-faceted series of criteria. The integration of architecture and landscape demonstrates maturity of a town/region in sustainably managing space, where informed understanding of cultural and natural landscape conservation in spatial planning and management should be an important element of planning policy. The integration of architecture and landscape is understood as a result of a synergy of factors influencing both the spatial and social factors, which consequently results in the formation of a basic and non-standard enclave, which sustains coherent and multi-functional social and cultural relationships. The effects of synergistic actions are mutually strengthening and complementary, and therefore more important than the sum of the individual factors considered [2].

In order to integrate architecture and landscape in the designing and planning of construction projects, proper consideration of aesthetic, socio-cultural, functional and location-specific factors must be made. In addition, there is a need to conduct specifically designed studies, which take into account the reference to the original (founding) character of a town (Figure 1).

The first step was to select the construction projects to be evaluated (step 1, Figure 1) 11 investments (hotels, luxury residential buildings and hotel suites) completed in 2009-2020 or in the final phase of the investment process (completion planned for 2021) were selected for the analysis. The location factor was important in selecting the investment-all of them are located on the coast in the region of Western Pomerania, in touristic seaside towns, near the beach and the sea.

To ensure a full evaluation was made, it was important to carry out interpretative and historical studies (step 2, Figure 1) to identify the characteristics of a seaside resort in its 
original, founding form, the uniqueness and identity of the locality and its leisure- and tourism-related functionality. This was important to establish a reference point for the evaluation of current construction projects. Interpretive and historical desk research included investigating the iconology and iconography of the region, including interpretations of graphic representations (e.g., historical postcards, photographs, maps) and historiography, which deals with archival research (e.g., archive documents, journals, books). These source materials were obtained primarily from the municipal offices, the Regional Office for the Protection of Monuments, National Digital Archive as well as other archived materials.

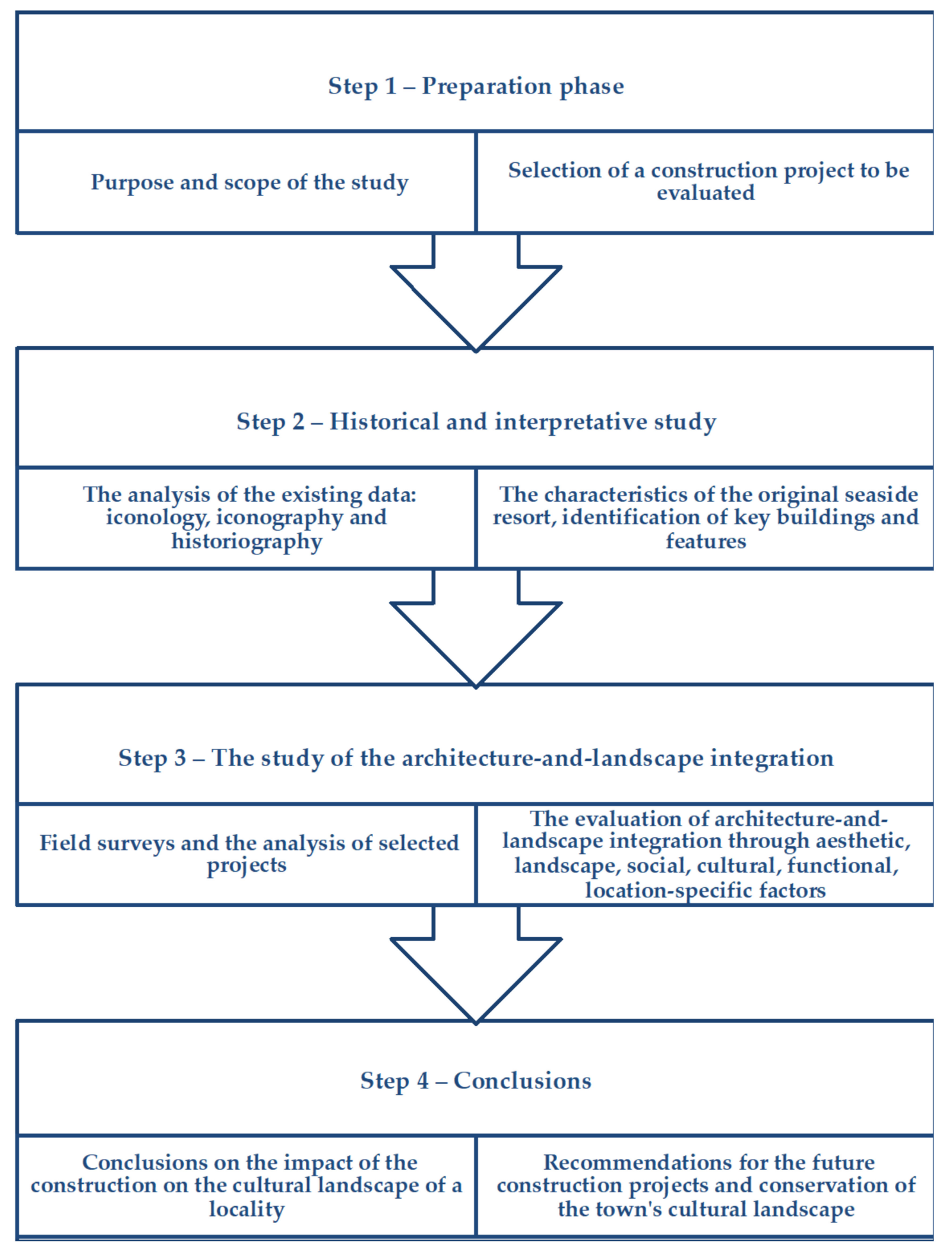

Figure 1. Study methodology diagram. Source: Authors' work. 
The third step was examining the degree of landscape-and-architecture integration using a pre-prepared form, which assigned a score for different criteria relating to four groups of factors (aesthetic, socio-cultural, functional and locational). The individual criteria were evaluated using both field surveys and desk research (e.g., analysis of construction plans and source information available in the press or on the internet). This analysis covered town-planning, landscape, aesthetic, cultural, social and natural aspects, providing a holistic take on the assessment of architecture-and-landscape integration. During the field surveys, data was collected on a building sheet form. Particular attention was taken to assess the coastal strip which includes the Maritime Office, dunes, protected cliffs and national parks, which are subject to other forms of landscape protection and which frequently implement local spatial development plans (land use plans). However, detailed analysis of coastal cliff erosion caused by the increased number and congestion of planned construction projects in the close vicinity of the seacoast has not been made.

Based on the evaluation of architecture-and-landscape integration, the fourth methodological step had two objectives. Firstly, it identified the characteristics of the architectural features or town-planning establishments, which were being evaluated. Secondly, it compared those characteristics with those identified as central to the original, founding concept of the seaside resort. Based on this information, the final step was to draw conclusions on the degree of architecture-and-landscape integration implemented in current construction projects and to provide recommendations for future development, management and conservation of the cultural landscape.

The research method developed here is universally applicable and can therefore be used to evaluate the degree of architecture-and-landscape integration in selected architectural and urban-planning projects in seaside resorts, located in different global locations. However, the specific details of a locality and its characteristics must always be determined based on relevant historic and interpretative studies.

\section{Results}

\subsection{Historical and Interpretative Study}

Tourist destinations located on the Baltic coast were generally developed from fishing settlements or small port towns at the end of the 19th century. However, in Western Pomerania, most of the resorts developed later in the interwar period (1918-1939), evolving from existing settlements and localities into so-called summer resorts, health resorts or resorts (various forms and scales of holiday resorts). The English models, which were initially used to shape coastal towns, have since been replaced with the original style of buildings [46] and the Polish expression of a resort with its more unique architectural and urban characteristics [1]. In the first two decades of the 20th century, Pomerania's seaside resorts began to stand out with a nearly-uniform, clearly defined spatial and functional layout, in line with the architectural style of private residences and public buildings. The specific character and nature of a resort was shaped by the upper-class style of recreation. The resulting need to experience luxury, opulent aesthetics and a desire to develop intellectually in a variety of forms, has influenced the way in which the town was shaped, matched by the exquisite lifestyle and expectations of the guests (the subject of the evolution of resorts and the search for their new cultural identity has been discussed in greater detail both in the previous article by the authors "The stages of the cultural landscape transformation of seaside resorts in Poland against the background of the evolving nature of tourism" published in this journal and in many previous studies $[1,2,46])$.

Archived source material was obtained from the Regional Office for the Protection of Monuments, National Digital Archive and other online archives. Analysis of these references allowed the identification of key elements and characteristics of the towns' development and composition, including nodal enclosed structures, multi-threaded architectural features or how the use of public space has changed over time as the mature form of a seaside resort emerged (Table 1). 
Table 1. The key compositional elements and characteristics of a mature seaside resort. Source: Authors' work.

\begin{tabular}{|c|c|c|c|}
\hline $\begin{array}{l}\text { Elements of } \\
\text { the Resort }\end{array}$ & $\begin{array}{l}\text { Buildings and } \\
\text { Features }\end{array}$ & Style and Functional Characteristics & Importance in the Landscape \\
\hline \multirow{2}{*}{$\begin{array}{l}\text { Linear } \\
\text { Elements }\end{array}$} & Promenade & $\begin{array}{c}\text { Formal structure of the space, numerous small } \\
\text { architectural elements (e.g., fountains) and plant } \\
\text { features (flower beds), with an absence of tall trees } \\
\text { which would block the view of the sea }\end{array}$ & $\begin{array}{l}\text { Promenade runs parallel to the } \\
\text { shoreline, linking other elements of } \\
\text { the town, creating a scenic sequence } \\
\text { (linear view of the sea and dunes), } \\
\text { strong visual links with the sea }\end{array}$ \\
\hline & Pier & $\begin{array}{c}\text { This element functions both as a dock/harbor and } \\
\text { a promenade, with light, wooden buildings, } \\
\text { usually one-storied with sculpted roofs } \\
\text { The Pier includes the following elements: the } \\
\text { dock/harbor, a gallery, a restaurant, } \\
\text { changing rooms }\end{array}$ & $\begin{array}{l}\text { Pier is perpendicular to the } \\
\text { coastline, extending from the } \\
\text { promenade, with a view of the } \\
\text { buildings along the coastline, } \\
\text { forming the town's distinctive "sea } \\
\text { gateway" / "welcome gate" }\end{array}$ \\
\hline \multirow{4}{*}{$\begin{array}{l}\text { Nodal } \\
\text { Elements }\end{array}$} & Spa House & $\begin{array}{l}\text { Has distinctive characteristics for the resort } \\
\text { architecture; forming an elegant architecture as } \\
\text { part of a grandiose building }\end{array}$ & $\begin{array}{l}\text { The Spa house is most often an } \\
\text { enclosed building, in the immediate } \\
\text { vicinity of the dune strip }\end{array}$ \\
\hline & Theatre/Bandshell & $\begin{array}{l}\text { Elegant architecture, where the buildings satisfy } \\
\text { cultural needs, contributing to its functional range }\end{array}$ & $\begin{array}{l}\text { Objects that complement the } \\
\text { composition and function }\end{array}$ \\
\hline & Beach Bathrooms & $\begin{array}{l}\text { Distinctive U-shaped wooden structure situated } \\
\text { adjacent to the sea, with a consistent form along } \\
\text { the coast; a provisional character }\end{array}$ & $\begin{array}{l}\text { Characteristic feature of the beach, } \\
\text { a landmark }\end{array}$ \\
\hline & $\begin{array}{l}\text { Dock/Harbor } \\
\text { Station }\end{array}$ & $\begin{array}{l}\text { Sometimes connected to a pier (at the end of the } \\
\text { pier), it supplemented transport to the coast }\end{array}$ & Panoramic sea view \\
\hline \multirow{2}{*}{$\begin{array}{l}\text { Surface } \\
\text { Features }\end{array}$} & Beach & $\begin{array}{c}\text { Divided into bathing water for women, men and } \\
\text { families. Additional features include wooden } \\
\text { bathing buildings (bathrooms), piers, marinas } \\
\text { and decks }\end{array}$ & $\begin{array}{l}\text { Alternating and temporary } \\
\text { character (lightweight structures), } \\
\text { absence of a fixed boundary, } \\
\text { numerous cultural elements, } \\
\text { varied availability }\end{array}$ \\
\hline & Spa Park & $\begin{array}{l}\text { Landscaped or geometric style, with important } \\
\text { functional significance-the park accommodates } \\
\text { buildings important for clients (spa house, water } \\
\text { drinking rooms) with numerous small } \\
\text { architectural elements (garden houses, kiosks, } \\
\text { fountains), as well as rich tree stands including } \\
\text { exotic species }\end{array}$ & $\begin{array}{l}\text { The composition of the park is } \\
\text { connected to the town by the layout } \\
\text { of the alleys and streets, as is a } \\
\text { carefully composed and integrated } \\
\text { part of the seaside quarter }\end{array}$ \\
\hline $\begin{array}{l}\text { Point } \\
\text { elements }\end{array}$ & $\begin{array}{l}\text { Villas, Guest Houses } \\
\text { and Hotels }\end{array}$ & $\begin{array}{l}\text { Buildings with skeleton-like forms and luxurious } \\
\text { finishes, including balconies, verandas, oriel } \\
\text { windows, triangular gables ("Swiss style"-the } \\
\text { late 19th century and Norwegian until 1910) }\end{array}$ & $\begin{array}{l}\text { Harmony and consistency in } \\
\text { the landscape }\end{array}$ \\
\hline
\end{tabular}

The model composition elements of seaside resorts on the southern Baltic Sea includes four groups: (1) linear elements modelled on English resorts established earlier: a promenade and pier (Figure 2a,b); (2) nodal elements: a spa house, a water drinking rooms, a casino, a bandshell and a theatre, beach bathrooms, a dock/harbor (Figure 3a-d); (3) surface elements: beach, spa park (Figure 4a,b); and (4) point elements: villas, guest houses, hotels (Figure 5a,b). The public spaces played an important role in the town's vibrancy, representing a kind of an elitist drawing room. Along a seaside promenade, where social interaction flourished and concentrated, the space was more functionally arranged and composed. The promenade connected the important features for resort life (a spa resort, a spa garden, beach bathrooms, pier, etc.) and provided a linear view overlooking the sea, due to the occasional point-wise development in the dune strip. The resort's architecture was characterized by a rich finish and was functionally adapted to the expectations of the upper class. Villas, guest houses and hotels were commonly designed in the "Swiss style," which is synonymous with a wooden summer-resort (late 19th century). Typically, 
they were two- or three-story wooden buildings with bay windows, sophisticated towers, balconies and verandas, which were designed to ensure openness and integration with the landscape. The defining characteristics of public space and architecture were logic, order, harmony, coherence, elitism, elegance and strong water-land links, but with limited impact on the landscape.

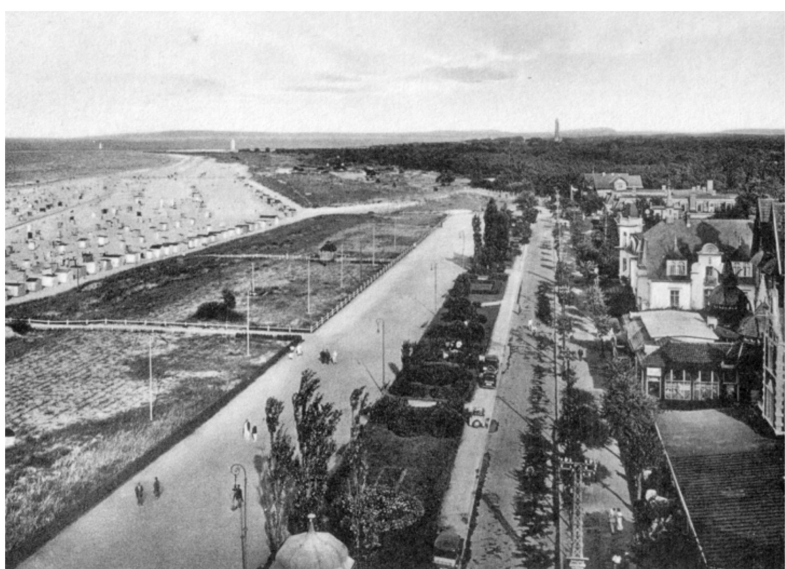

(a)

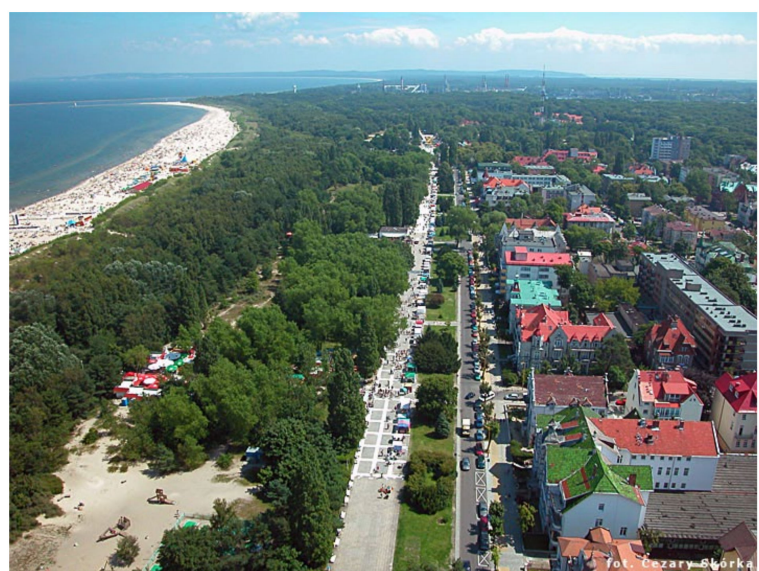

(b)

Figure 2. Linear elements: A bird's-eye view of the promenade in Świnoujście: (a) A postcard from the beginning of the 20th century; (b) Photo from 2004. Source: Scans of archival postcards-Private collection of the author (a), Cezary Skórka (b).

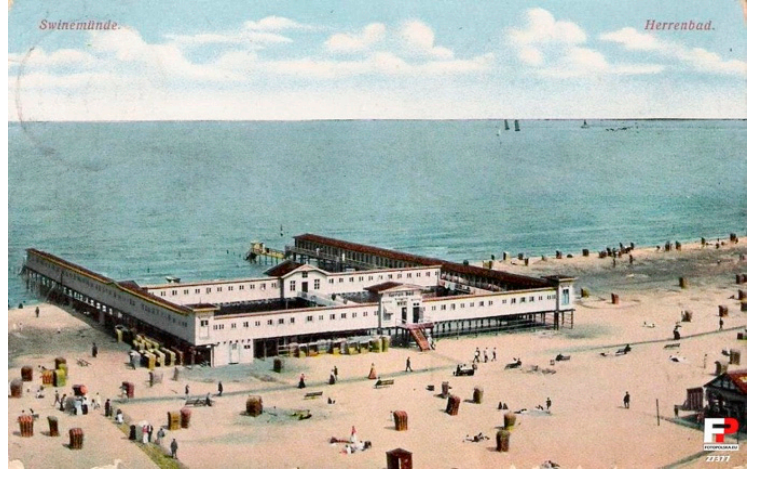

(a)

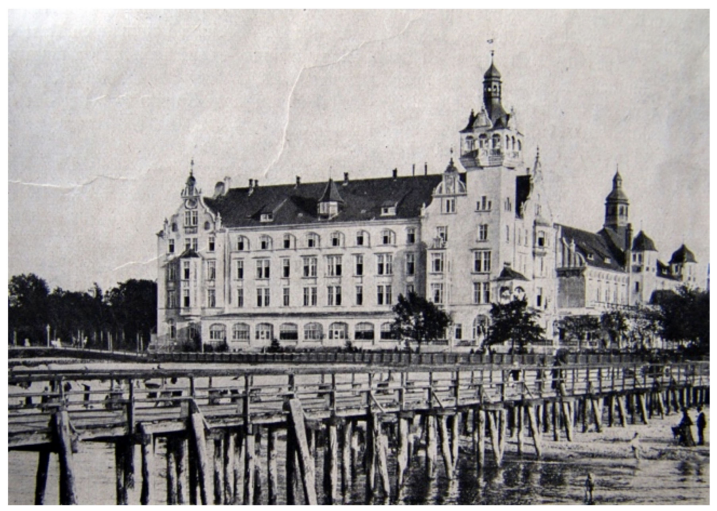

(c)

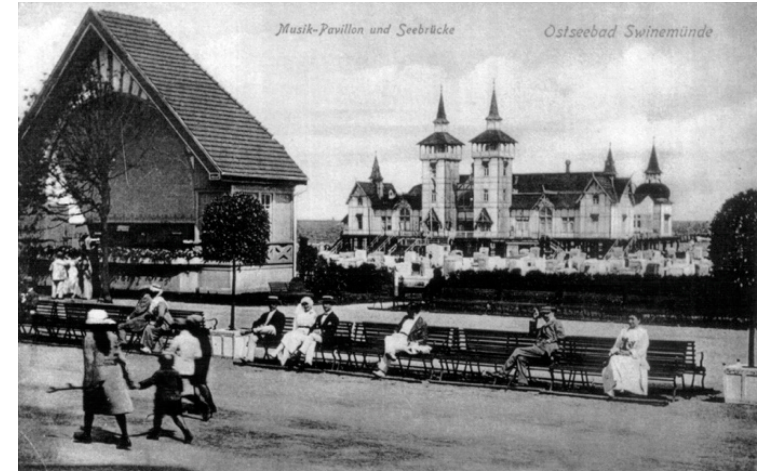

(b)

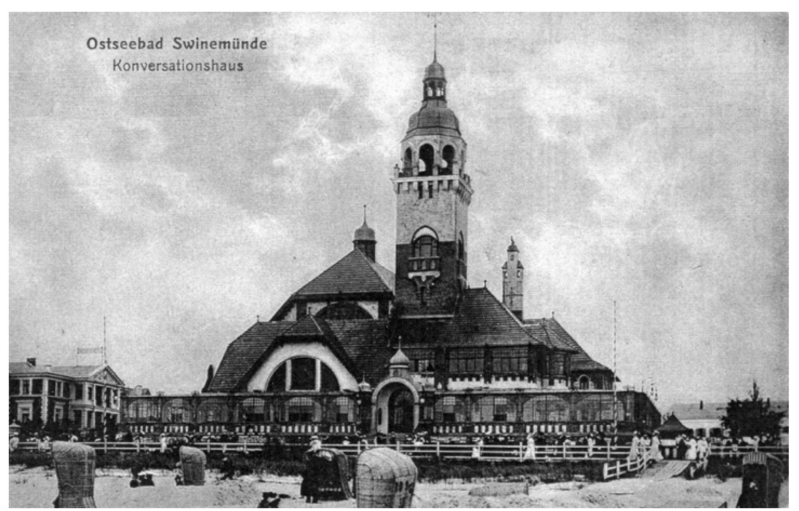

(d)

Figure 3. Nodal elements: (a) Swimming area in Świnoujście; (b) Concert shell and beach palace (c) Spa house in Kołobrzeg; (d) Spa house in Świnoujście. Source: Fotopolska.pl (a), Scans of archival postcards-Private collections of the author (b,d), Motzke P.; Deutchlands Stadtebau. Kolberg, Berlin-Halensee: “Dari” Verlag, 1921 (c). 


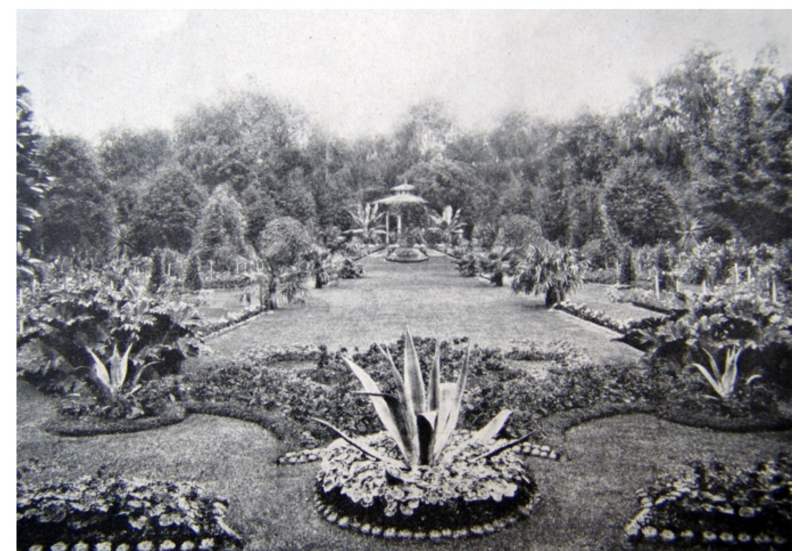

(a)

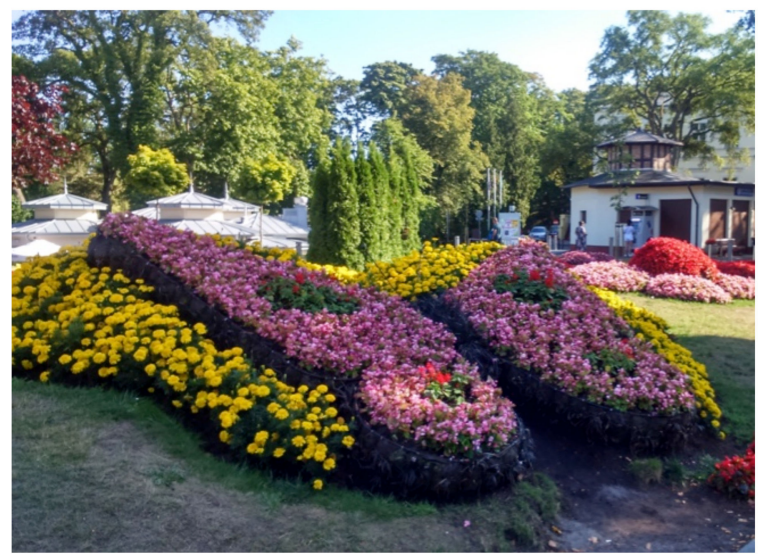

(b)

Figure 4. Surface elements: (a) Kołobrzeg Spa Park—the beginning of the 20th century, (b) Miedzyzdroje Spa Park—2018. Source: Motzke P.; Deutschlands Stadtebau. Kolberg, Berlin-Halensee: “Dari” Verlag, 1921 (a), Author's photo (b).

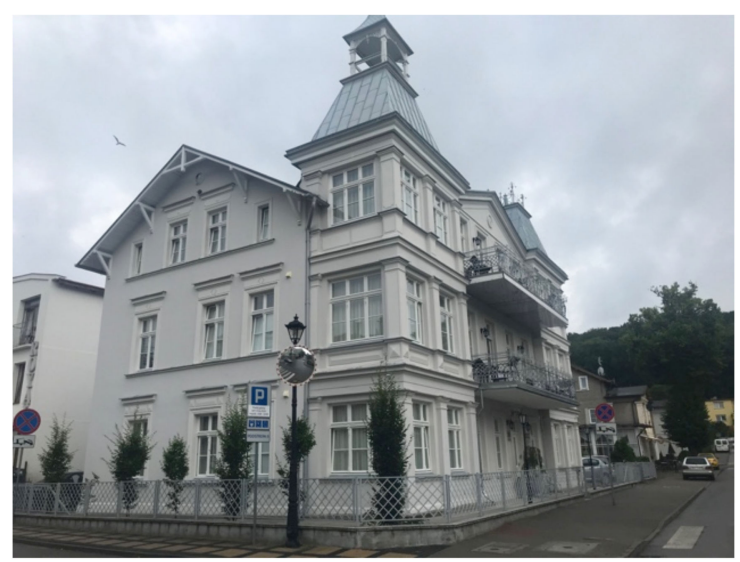

(a)

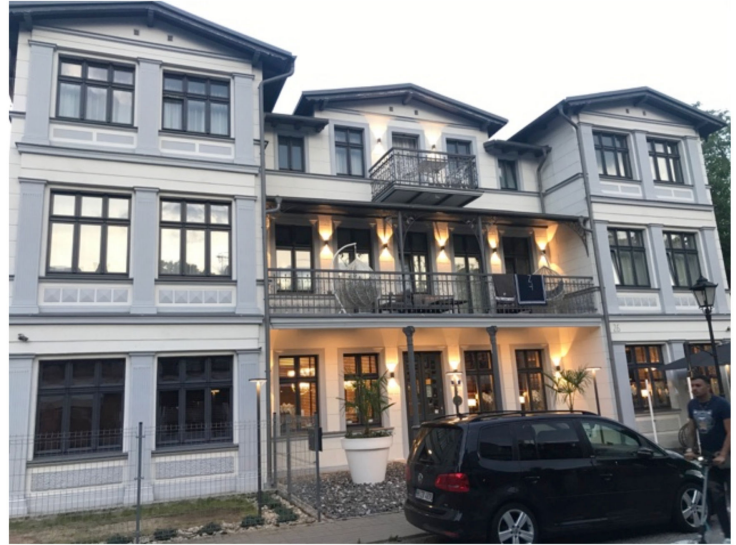

(b)

Figure 5. Point elements: Historic guesthouse buildings—facilities after adaptation and renovation: (a) guesthouse at Pomorska Street in Międzyzdroje), (b) guesthouse at Promenada in Międzyzdroje. Source: Author's photo (a,b).

\subsection{Examination of the Architecture-and-Landscape Integration}

Analysis of 11 new construction projects located in the Western Pomeranian seaside showed a relatively poor integration of architecture and landscape. The study was conducted for each construction project using a pre-prepared evaluation form (Appendix A, Figures A1-A11), which scores each project based on 20 criteria, grouped by four key factors: aesthetic, socio-cultural, functional and locational-natural. The maximum score that could be awarded from all criteria was 60 (including the maximum score in each factor group, 15) (Table 2).

The lowest scoring criteria for all projects occurred in the following groups: sociocultural factors (average score 5.27) and aesthetic factors (average score 6.34). These two groups include criteria that relate directly to the preservation of cultural continuity, therefore low scores in these groups of criteria show that a discord in cultural continuity where the original character of a location was not properly protected. Although the stylistic characteristics of the architecture did generally exhibit signs of consistency with historical buildings (e.g., scale, details, town-planning arrangement), the construction projects being analyzed were also characterized by buildings with a height, volume and footprint area significantly different from those of traditional, historical resort architecture (Figure 6a-c). 
Table 2. Summary of the scores for each construction project analysed using the building evaluation forms (Appendix A). Source: Authors' work.

\begin{tabular}{|c|c|c|c|c|c|}
\hline Construction Project & $\begin{array}{l}\text { Aesthetic } \\
\text { Factors }\end{array}$ & $\begin{array}{l}\text { Socio-Cultural } \\
\text { Factors }\end{array}$ & $\begin{array}{c}\text { Functional } \\
\text { (Practical) Factors }\end{array}$ & $\begin{array}{l}\text { Location-Related } \\
\text { and Natural Factors }\end{array}$ & Total Points \\
\hline Baltic Palace Hotel & 10 & 8 & 7 & 5 & 30 \\
\hline Baltic Park Molo & 8 & 11 & 11 & 8 & 38 \\
\hline Baltic Park Plaża & 3 & 6 & 6 & 5 & 20 \\
\hline Baltic Park Promenada & 12 & 10 & 9 & 10 & 44 \\
\hline Balticus Apartments & 3 & 5 & 6 & 5 & 19 \\
\hline Hotel Gołębiewski & 3 & 4 & 9 & 4 & 20 \\
\hline Marine Hotel & 11 & 8 & 8 & 8 & 35 \\
\hline Rogowo Pearl & 7 & 6 & 7 & 9 & 27 \\
\hline Porta Mare Wellness \& SPA & 4 & 3 & 6 & 7 & 20 \\
\hline Shellter Hotel \& Apartments & 5 & 7 & 7 & 7 & 26 \\
\hline Wave Apartments & 7 & 5 & 5 & 7 & 24 \\
\hline Average score & 6.34 & 5.27 & 7.36 & 6.82 & 27.54 \\
\hline
\end{tabular}

On the other hand, the functional factor criteria (average score 7.36) and the locationalnatural factor criteria (average score 6.82) were assessed relatively better, as the resort's function has continued to adhere to the original tradition of the region (resort-forming functions). This is because functional factor criteria are often intrinsically linked with the economic importance, accessibility and usability of the project for various functions. Projects, which scored lower for this group of factors, were mainly as a result of the construction of "dead" luxury residential buildings, whose function only seemed to match the idea of a resort, whilst their rooms remained vacant for the most of the year.

The use of seaside locations and the impact of a project on vegetation and a littoral zone ecology was also evaluated as part of the locational and natural factors. The vast majority of buildings were positively identified as using land in the vicinity of the beach during construction planning. The buildings assessed were typically arranged and shaped to capitalize on the seaside location, where the capacity of each building was designed to allow for a view of the sea from the suites and the building's proximity provided convenient access to the beach. The relationship between how the building was integrated into the waterfront and the surroundings space was evaluated less well. Over time, buildings are being constructed closer and closer to the beach, often at the expense of naturally valuable dunes and causing removal of tree stands, which disturbs the soil cohesion and necessitates installation of invasive geoengineering measures (Figure 7a,b). Another disadvantage is the construction of large complexes of buildings, which form isolated enclaves and cause the buildings to appear to merge along the coast. This strongly contrasts to traditional resort buildings, whose sizes were much smaller and fitted more harmoniously into the surrounding town, featuring lower buildings with smaller internal volume) and a greater distance between the buildings.

The highest score was awarded to the project called Baltic Park Promenada in Świnoujście, for which the sum of points was 44 , and the average score for each group of criteria was 11. The construction is a complex of five luxury residential buildings, and was one of the oldest of the projects analyzed. The buildings' architecture, despite resembling a Mediterranean seaside resort, was built prior to the extension and lengthening of the promenade in the eastern direction. The buildings in this project are distinguished by their traditional size/scale and point-wise dispersed layout, which has clearly been inspired by the structure of traditional guest houses (Figure 8a,b). 


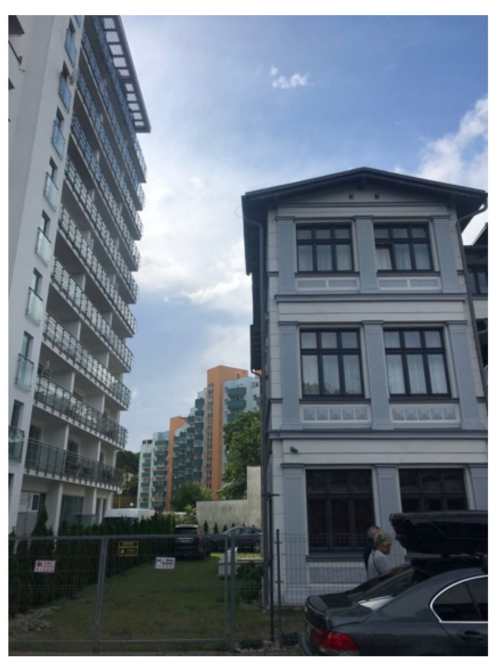

(a)

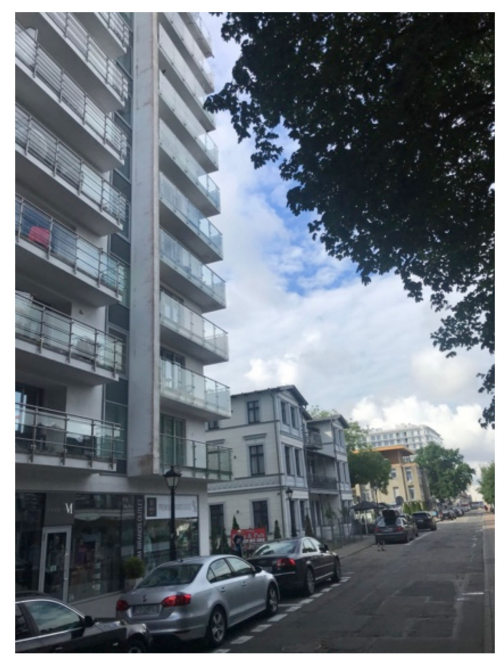

(b)

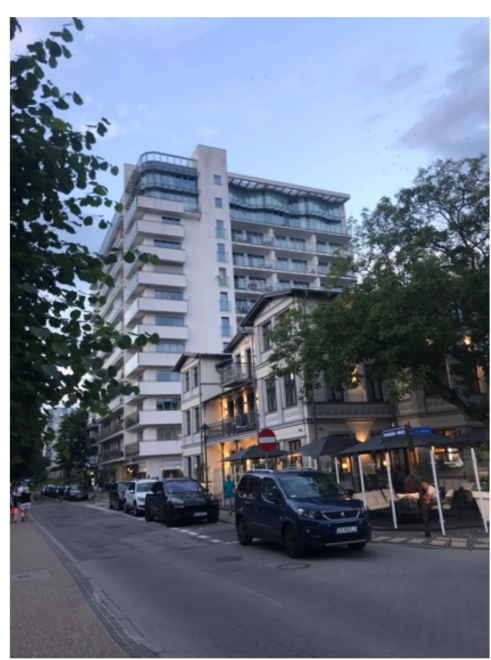

(c)

Figure 6. Międzyzdroje. Contrast of old and new buildings: changing the scale of buildings and the way of rest (a-c). Source: Author's photo $(\mathbf{a}-\mathbf{c})$.

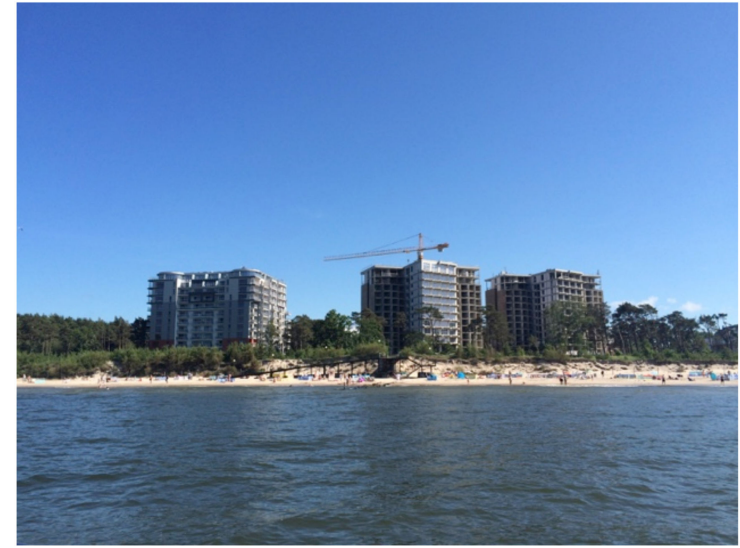

(a)

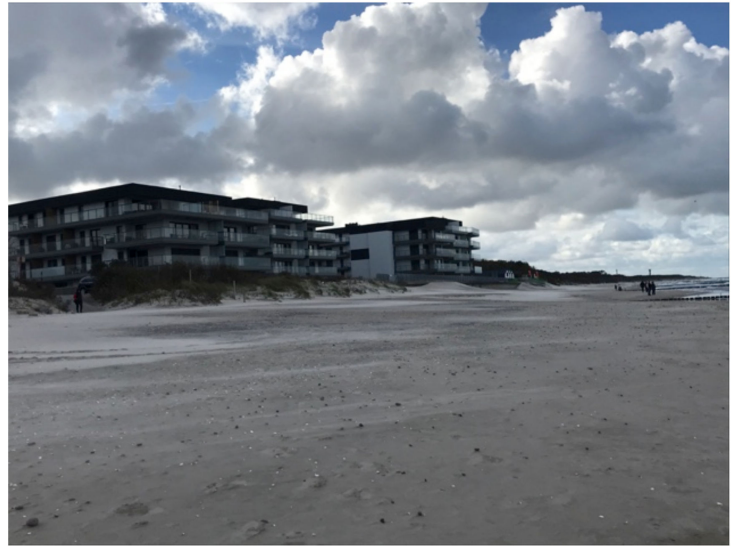

(b)

Figure 7. New buildings closer to the beach: (a) Dziwnówek. Porta Mare-extension and superstructure of the center from 1976-1983. (b) Dziwnów. Gardenia Seaside Apartments. Source: Author's photo (a [1], b).

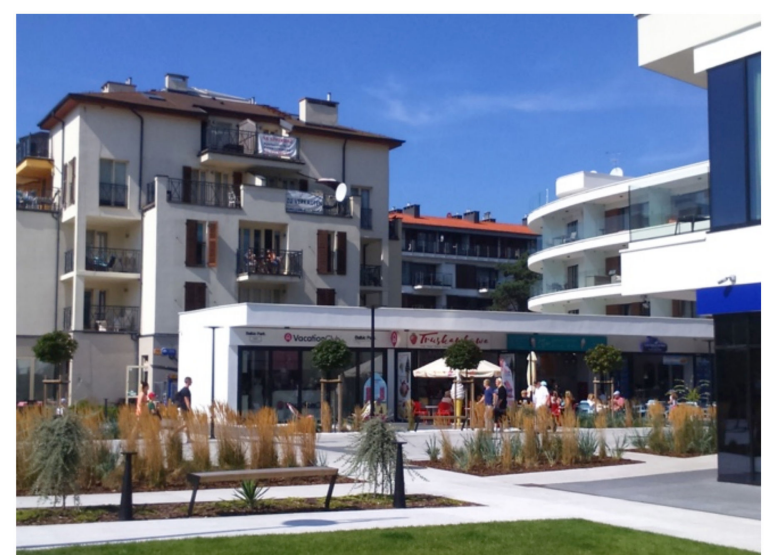

(a)

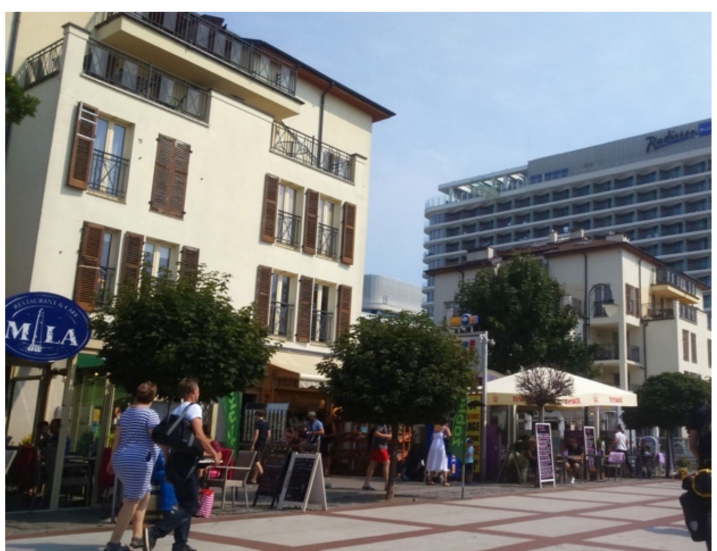

(b)

Figure 8. Świnoujście, Baltic Park Promenada $(\mathbf{a}, \mathbf{b})$. Source: Author's photo $(\mathbf{a}, \mathbf{b})$. 
On the other hand, the Balticus Apartments in Miedzyzdroje, which was the lowest scoring project, drastically diverged from the cultural continuity of the promenade, degrading the traditional landscape and depreciating the spatial order (Figure 9a,b). This project is a perfect example of very poor architecture-and-landscape integration, in virtually all of the examined groups of factors.

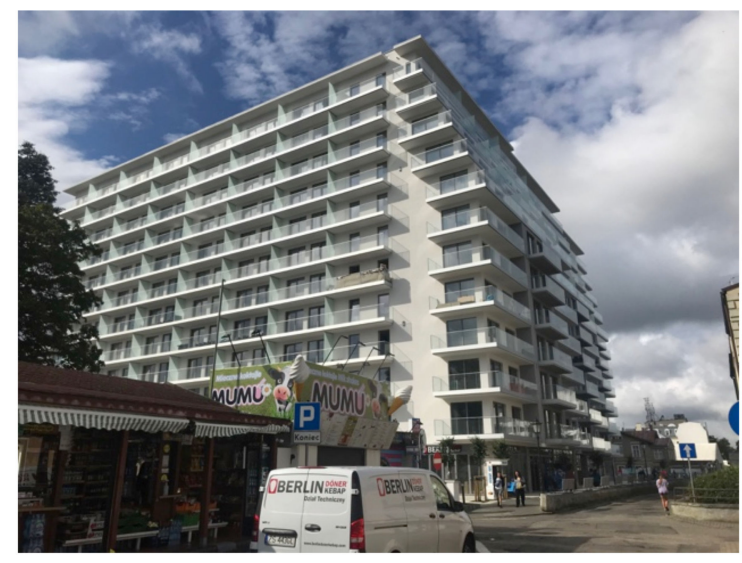

(a)

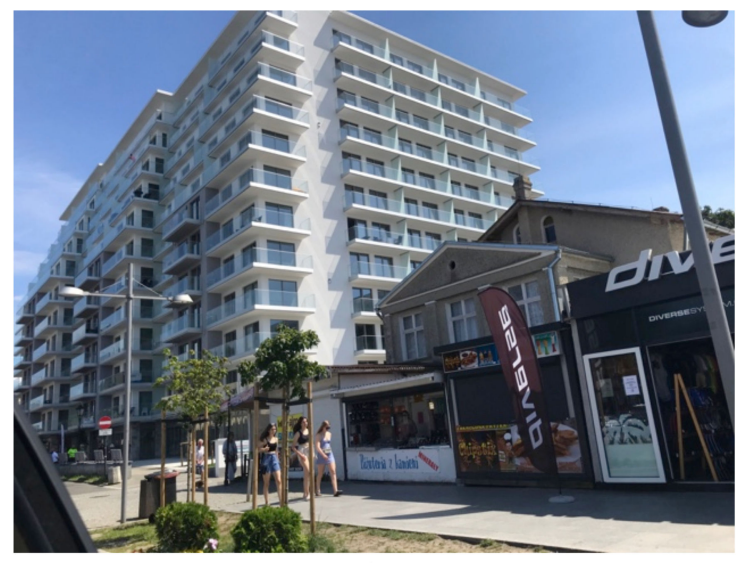

(b)

Figure 9. Miedzyzdroje, Balticus Apartments—an example of monstrous buildings in the central part of the resort (a,b). Source: Author's photo $(\mathbf{a}, \mathbf{b})$.

\section{Discussion}

A number of authors have suggested that resort development goes through a predictable sequence of stages: moving from a discovery stage to full tourism development [47-53]. Among them, Butler's Tourism Area Life Cycle [50], a general model of the evolution of a hypothetical tourist area, is one of the best-known and most cited concepts $[54,55]$. The few models that are strictly related to the coast and coastal towns include: Liszewski's phases of development of tourist space [25], Butowski's model of development of maritime tourism areas for sailing tourism [56,57], Gormsen's model of tourism development specific to coastal resort [58] and Smith's beach resort model [59]. It should be noted, however, that the developed models of tourism development are mostly general in nature and relate to aspects other than architecture and the impact of tourism development on the character and features of buildings [1]. Against this background, the model of Bal and Czalczynska [1] seems to be unique, as it refers to the specificity of seaside tourism architecture, combining two perspectives: the history of architecture and urban planning, and the development of tourism. The model consists of four basic stages of cultural landscape transformations of seaside resorts in Poland: Stage I: Formation-Elite resort (early 19th century-20th century); Stage II: Regionalism-National resort (1918-1939); Stage III: Socialization-A resort for working masses (1945-1989); Stage IV: Pluralism—Egalitarian resort (since 1989). Further development (Stage V) is possible in two directions: Unified pluralism-Network tourist destination or Secondary regionalization—Sustainable Resort [1].

Unfortunately, the analysis of contemporary tourism architecture on the coast shows that tourist destinations are developing rather towards unification and loss of regional features. The results of this study align with the previous observations, confirming that the increase of mass commercial tourism has a strong impact on the traditional landscape of coastlines and often causes severe spatial changes which destroy the cultural identity of a town. Also, along the Polish coast, the issues associated with "second-homes" [20,21] and the decreasing consideration for the tradition and uniqueness of a town [18] is becoming increasingly noticeable. Over time, this gradually leads to the destruction of landscape assets that originally attracted tourists [26]. Tourism has become a large-scale phenomenon 
that results in changes across all aspects of the landscape [60]. The tourism landscape can be a sensitive tool for analyzing geographical changes, although what drives these changes remains largely unknown [28]. Changes in the landscape, although inevitable [6], should be kept to a minimum in order to protect the uniqueness of traditional spaces. In general, the specific impact of tourism on seaside resorts has not been taken into account by commonly used methods for evaluating the cultural landscape. Furthermore, the development of tourism creates a conflict between economic growth and the preservation of landscape assets [61], which makes it difficult to draw up suitable evaluation criteria.

The method outlined in this study is a response to the growing problem of spatial disintegration, which is connected with the introduction of foreign elements within it that are functionally and morphologically unsuited to their surroundings, and awaken mostly negative feelings [62]. Therefore, the search for methods of landscape integration seems justified. In landscape architecture, the concept of integration refers to activities of landscape conservation, restoration of degraded landscapes [63] as well as merging the historic urban landscapes with the contemporary built-up areas [64]. In design practice, the integration of architecture and landscape is most often implemented in the design of buildings with organic, amorphous shapes and using trendy ecological and pro-environmental solutions. The developed method evaluates construction projects on the basis of criteria, which assess architecture-and-landscape integration, taking into account the tradition of the site and the uniqueness of the original seaside resort. This facilitates a critical evaluation of recent architectural and town-planning developments as well as the current trends in planning and designing of buildings in the seaside area. At the same time, social aspects, including the impact of projects on the economic development of a town, are also taken into account. The multi-faceted nature of this method is important, as management of tourism is a highly synergistic endeavor [65]. The developed research procedure can be used to evaluate investments in seaside towns located in various regions of the world. However, it should always be preceded by a locally appropriate historical analysis in order to define the features of the original resort. Working in a team and precisely defining the assessment criteria can minimize the subjectivity of the assessment.

\section{Conclusions}

Coastal areas are an extremely sensitive part of an uncontrolled town-planning experiment, which leads to a rapid loss of the original (founding) features of the area [66]. The intensive growth of tourism causes the original concept of a seaside resort to become distorted, where the unique characteristics of seaside towns that was once their assets are destroyed or devalued. This reduces the importance of public spaces, which were originally a key part of resort life. Traditional hotels and guest houses are increasingly being replaced by large luxury residential complexes with new buildings which do not conform to the local scale and follow a non-physiognomic design which become dominant in seaside locations. As a result, modern seaside resorts of Western Pomerania are now characterized by aesthetic chaos, with a functional and spatial disarrangement and poor spatial order.

The analysis undertaken in this study helped identify the specific negative impacts of tourism development on the cultural landscape of seaside resorts, including:

- the construction of "inactive" luxury residential buildings that remain vacant for most of the year and are a dead urban tissue;

- $\quad$ island-like buildings-large, self-sufficient buildings, which form individual islands which are isolated from the surrounding space, contrasting with the traditional development of resorts which are also present in the seaside landscape;

- linear, band-like, congested development of the waterfront-it is increasingly evident that there is a fusion of coastal towns as they have expanded laterally along the coast and have begun to merge, with an increasingly uniform structure, as in the western countries; 
- An imperfect, deficient planning process is lacking the input of experts to with regards to the planning and implementation of development projects, where local authorities do not require consideration of results from landscape analyses and studies, social discussions, or more informed shaping of holiday areas;

- The lack of an appropriate tool for the evaluation of planned construction projects in terms of conservation and protection of seaside resorts reflects the economically driven and short-sighted policies of local governments, which are considered more important than protecting their landscape assets. This has resulted in the completion of developments that have distorted the cultural continuity and devalued the landscape.

The problems identified in this study require urgent action in seaside resorts to protect their cultural landscape, as it is a key asset for its tourism industry. In the long term, the squandering of the uniqueness of the former resort can result in losses not only of cultural importance, but also have a damaging impact on the local economy due to the reduction in the attractiveness of the location as a tourist destination. Therefore, it appears imperative:

- to conduct analyses and studies on landscape evaluation in localities which still resemble the original features of the traditional resorts; these assessments would serve to draw up guidelines for updating local development strategy documents (master plans) and local spatial development plans;

- a town or locality with a similar nature to that of an original resort should be given a special status/designation, to ensure that it is properly governed by regulations for the establishing, management and planning as a cultural park, with suitable conservation plans which will enable these valuable landscapes to be protected;

- create a system/tool for designers and local governments to form of a code of best practice, to ensure proper conduct during the planning process and which takes into account the synergies between the architecture and landscape of seaside resorts.

Although this study does not completely explore the impact of tourism development on landscape of seaside resorts, the methodology described here can provide a useful tool to look critically at development projects recently completed along the coast and aid projection of future trends. It is desirable to pursue further studies which aim to draw up guidelines for local development plans that will reconcile the growth of tourism in a town, with the conservation of the resort's original values at heart. The criteria of architecture-and-landscape integration can be an important reference point, allowing for a comprehensive and multi-faceted approach to planning and designing.

Author Contributions: Conceptualization, W.B. and M.C-P.; Methodology, W.B. and M.C.-P.; Formal Analysis, W.B. and M.C.-P.; Investigation, W.B. and M.C.-P.; Resources, W.B. and M.C.-P.; Writing-Original Draft Preparation, W.B. and M.C.-P.; Writing-Review \& Editing, W.B. and M.C.-P.; All authors have read and agreed to the published version of the manuscript.

Funding: This research received no external funding.

Data Availability Statement: The data presented in this study are available in Appendix A. Figures A1-A11.

Conflicts of Interest: The authors declare no conflict of interest.

\section{Appendix A}

Figures A1-A11: construction project analysis form-building sheet. 
Construction project analysis form - Building sheet

\begin{tabular}{|l|l|l|l|}
\hline \multicolumn{3}{l}{ Construction project analysis form - Building sheet } \\
\hline Building name & Field survey information \\
\hline Baltic Palace Hotel & $\begin{array}{l}\text { Date 1: September } \\
2019\end{array}$ & $\begin{array}{l}\text { Date 2: September } \\
2020\end{array}$ \\
\hline Location & Description & \\
\hline Pobierowo & $\begin{array}{l}\text { A boutique hotel, 4-cond. building with a } \\
\text { SPA zone. } \\
\text { Architects: Mateusz Tański and Piotr } \\
\text { Michalewicz }\end{array}$ & & Source: Author's work \\
\hline Year(s) of construction & Study conditions & 30 & Average score \\
\hline 2010-2015 & Sunny weather, quite warm & $\mathbf{3 0}$ \\
\hline
\end{tabular}

\section{Aesthetic factors}

\begin{tabular}{|c|c|c|c|c|c|}
\hline \multirow[t]{2}{*}{ Criteria } & \multicolumn{4}{|c|}{ Score for the construction project } & \multirow[t]{2}{*}{ Comments } \\
\hline & 0 & 1 & 2 & 3 & \\
\hline $\begin{array}{l}\text { 1. Scale - the degree to which the project matches with the surrounding } \\
\text { architecture }\end{array}$ & & & $x$ & & \\
\hline $\begin{array}{l}\text { 2. Colours and materials - the degree to which the project matches with } \\
\text { the surrounding architecture }\end{array}$ & & $x$ & & & \\
\hline $\begin{array}{l}\text { 3. Form - the degree to which the building matches with the surrounding } \\
\text { architecture }\end{array}$ & & & $\mathrm{x}$ & & $\begin{array}{l}\text { Shape of the building } \\
\text { inspired by modernist } \\
\text { architecture, unusual, } \\
\text { asymmetrical silhouette }\end{array}$ \\
\hline $\begin{array}{l}\text { 4. Nature of the original resort - the degree to which the project is inspired } \\
\text { by traditional or regional stylistic features of the resort }\end{array}$ & & & $\mathrm{x}$ & & \\
\hline $\begin{array}{l}\text { 5. Uniqueness - the degree to which customized solutions and new } \\
\text { stylistic features are introduced }\end{array}$ & & & & $x$ & $\begin{array}{l}\text { The building is } \\
\text { distinguished by the form } \\
\text { and shaping of the facade }\end{array}$ \\
\hline
\end{tabular}

Socio-cultural factors

\begin{tabular}{|c|c|c|c|c|c|}
\hline \multirow[t]{2}{*}{ Criteria } & \multicolumn{4}{|c|}{ Score for the construction project } & \multirow[t]{2}{*}{ Comments } \\
\hline & $\mathbf{0}$ & $\mathbf{1}$ & 2 & 3 & \\
\hline 1. Social acceptance - how well local community accepts the project & & & $\mathrm{x}$ & & \\
\hline $\begin{array}{l}\text { 2. Cultural importance - the importance of the project in continuing the } \\
\text { resort's founding ideas }\end{array}$ & & & $x$ & & \\
\hline $\begin{array}{l}\text { 3. Identity - the degree to which the project refers to the tradition of the } \\
\text { space and how it emphasises the local cultural identity }\end{array}$ & & $x$ & & & \\
\hline $\begin{array}{l}\text { 4. Societal participation - the degree to which the opinions and needs of } \\
\text { the local community are taken into account in the construction project }\end{array}$ & & $\mathbf{x}$ & & & \\
\hline $\begin{array}{l}\text { 5. Good practice - the degree to which high-quality solutions are } \\
\text { promoted; whether the design was selected in a competition }\end{array}$ & & & $\mathrm{x}$ & & \\
\hline
\end{tabular}

Functional factors

\begin{tabular}{|c|c|c|c|c|c|}
\hline \multirow[t]{2}{*}{ Criteria } & \multicolumn{4}{|c|}{ Score for the construction project } & \multirow[t]{2}{*}{ Comments } \\
\hline & 0 & 1 & 2 & 3 & \\
\hline $\begin{array}{l}\text { 1. "Resort-creating" function-importance of the construction project for } \\
\text { the town's function as a seaside resort }\end{array}$ & & & $\mathrm{x}$ & & \\
\hline $\begin{array}{l}\text { 2. Local plan - the level of provisions implemented as part of the local } \\
\text { development plan }\end{array}$ & & $\mathrm{x}$ & & & \\
\hline $\begin{array}{l}\text { 3. Economic importance - the importance of the construction project for } \\
\text { the improvement of the town's life and economic development }\end{array}$ & & & $\mathrm{x}$ & & \\
\hline $\begin{array}{l}\text { 4. Green solutions - the degree to which green solutions are taken into } \\
\text { account }\end{array}$ & & $\mathbf{x}$ & & & \\
\hline $\begin{array}{l}\text { 5. Accessibility - to what extent a construction project is adapted to the } \\
\text { needs of various user groups; whether the building can be utilised }\end{array}$ & & $\mathbf{x}$ & & & \\
\hline
\end{tabular}

\section{Location-related and natural factors}

\begin{tabular}{|c|c|c|c|c|c|}
\hline \multirow[t]{2}{*}{ Criteria } & \multicolumn{4}{|c|}{ Score for the construction project } & \multirow[t]{2}{*}{ Comments } \\
\hline & 0 & 1 & 2 & 3 & \\
\hline $\begin{array}{l}\text { 1. Impact on vegetation - the degree to which the natural vegetation is } \\
\text { protected }\end{array}$ & & $x$ & & & \\
\hline $\begin{array}{l}\text { 2. Impact on the littoral zone - the degree to which erosion of dunes and } \\
\text { coastline is prevented }\end{array}$ & & & & & Not applicable \\
\hline $\begin{array}{l}\text { 3. Climate change - the degree to which climate change mitigation } \\
\text { solutions are considered }\end{array}$ & & $x$ & & & \\
\hline $\begin{array}{l}\text { 4. Landscape assets (amenities) - the degree to which the waterfront } \\
\text { panorama integrates with surroundings, including how they are } \\
\text { connected/linked in space }\end{array}$ & & $\mathrm{x}$ & & & \\
\hline $\begin{array}{l}\text { 5. Location-related assets - the degree to which the seaside location and } \\
\text { the adjacency of beach are utilized and emphasized in the construction } \\
\text { project planning }\end{array}$ & & & $\mathrm{x}$ & & \\
\hline
\end{tabular}

\footnotetext{
'The evaluation on a scale of 0 to 4 , where 0 means that the criterion is least considered, not considered or intentionally neglected during completion of the project.
}

Figure A1. Baltic Palace Hotel in Pobierowo. Building sheet. 
Construction project analysis form - Building sheet

\begin{tabular}{|l|l|l|l|}
\hline Building name & \multicolumn{3}{|l|}{ Field survey information } \\
\hline Baltic Park Molo & $\begin{array}{l}\text { Date 1: August } \\
2019\end{array}$ & $\begin{array}{l}\text { Date 2: August } \\
2020\end{array}$ \\
\hline Location & Description & $\begin{array}{l}\text { A complex of four buildings (including } \\
\text { Radisson Blu and Hilton Swinoujscie } \\
\text { Resort \& Spa) with public space located } \\
\text { between them. }\end{array}$ \\
\hline Swinoujscie & Study conditions & Source: swinoujskie.info \\
\hline Year(s) of construction & Sunny weather, quite warm & 38 & Average score \\
\hline 2013-2020 & & & 1.8 \\
\hline
\end{tabular}

\begin{tabular}{|c|c|c|c|c|c|}
\hline \multirow[t]{2}{*}{ Criteria } & \multicolumn{4}{|c|}{$\begin{array}{l}\text { Score for the construction } \\
\text { project }\end{array}$} & \multirow[t]{2}{*}{ Comments } \\
\hline & 0 & 1 & 2 & 3 & \\
\hline $\begin{array}{l}\text { 1. Scale - the degree to which the project matches with the surrounding } \\
\text { architecture }\end{array}$ & & $x$ & & & \\
\hline $\begin{array}{l}\text { 2. Colours and materials - the degree to which the project matches with the } \\
\text { surrounding architecture }\end{array}$ & & & & $x$ & $\begin{array}{l}\text { Natural colors of the earth } \\
\text { and sea flora }\end{array}$ \\
\hline $\begin{array}{l}\text { 3. Form - the degree to which the building matches with the surrounding } \\
\text { architecture }\end{array}$ & & & $x$ & & \\
\hline $\begin{array}{l}\text { 4. Nature of the original resort-the degree to which the project is inspired } \\
\text { by traditional or regional stylistic features of the resort }\end{array}$ & & $\mathrm{x}$ & & & \\
\hline $\begin{array}{l}\text { 5. Uniqueness - the degree to which customized solutions and new stylistic } \\
\text { features are introduced }\end{array}$ & & $\mathrm{x}$ & & & High-quality public space \\
\hline
\end{tabular}

\section{Socio-cultural factors}

\begin{tabular}{|l|l|l|l|l|l|}
\hline Criteria & \multicolumn{3}{|c|}{ Ocena inwestycii } & Comments \\
\cline { 2 - 6 } & $\mathbf{0}$ & $\mathbf{1}$ & $\mathbf{2}$ & $\mathbf{3}$ & \\
\hline 1. Social acceptance - how well local community accepts the project & & & & $\mathrm{x}$ & \\
\hline $\begin{array}{l}\text { 2. Cultural importance - the importance of the project in continuing the } \\
\text { resort's founding ideas }\end{array}$ & & & $\mathrm{x}$ & & \\
\hline $\begin{array}{l}\text { 3. Identity - the degree to which the project refers to the tradition of the } \\
\text { space and how it emphasises the local cultural identity }\end{array}$ & & & $\mathbf{x}$ & & \\
\hline $\begin{array}{l}\text { 4. Societal participation - the degree to which the opinions and needs of the } \\
\text { local community are taken into account in the construction project }\end{array}$ & & $\mathrm{x}$ & & & \\
\hline $\begin{array}{l}\text { 5. Good practice - the degree to which high-quality solutions are promoted; } \\
\text { whether the design was selected in a competition }\end{array}$ & & & & $\mathrm{x}$ & $\begin{array}{l}\text { Project selected in an } \\
\text { architecturac competition } \\
\text { organized by the investor } \\
\text { and SARP }\end{array}$ \\
\hline
\end{tabular}

\begin{tabular}{|c|c|c|c|c|c|}
\hline \multirow{3}{*}{ Criteria } & \multirow{2}{*}{\multicolumn{4}{|c|}{ Ocena inwestycji }} & \multirow{3}{*}{ Comments } \\
\hline & & & & & \\
\hline & 0 & 1 & 2 & $\frac{3}{x}$ & \\
\hline $\begin{array}{l}\text { 1. "Resort-creating" function - importance of the construction project for the } \\
\text { town's function as a seaside resort }\end{array}$ & & & & & \\
\hline $\begin{array}{l}\text { 2. Local plan - the level of provisions implemented as part of the local } \\
\text { development plan }\end{array}$ & & & $x$ & & $\begin{array}{l}\text { Hotels play the role of } \\
\text { dominants and } \\
\text { subdominants in the } \\
\text { landscape }\end{array}$ \\
\hline $\begin{array}{l}\text { 3. Economic importance - the importance of the construction project for the } \\
\text { improvement of the town's life and economic development }\end{array}$ & & & & $x$ & \\
\hline $\begin{array}{l}\text { 4. Green solutions - the degree to which green solutions are taken into } \\
\text { account }\end{array}$ & & & $x$ & & $\begin{array}{l}\text { Hilton Swinoujscie Resort \&s } \\
\text { Spa - facility built in } \\
\text { accordance with the LEED } \\
\text { ecological certification }\end{array}$ \\
\hline $\begin{array}{l}\text { 5. Accessibility - to what extent a construction project is adapted to the } \\
\text { needs of various user groups; whether the building can be utilised }\end{array}$ & & $x$ & & & \\
\hline
\end{tabular}

\begin{tabular}{|c|c|c|c|c|c|}
\hline \multirow[t]{2}{*}{ Criteria } & \multicolumn{4}{|c|}{ Ocena inwestycji } & \multirow[t]{2}{*}{ Comments } \\
\hline & 0 & 1 & 2 & 3 & \\
\hline $\begin{array}{l}\text { 1. Impact on vegetation - the degree to which the natural vegetation is } \\
\text { protected }\end{array}$ & $x$ & & & & \\
\hline $\begin{array}{l}\text { 2. Impact on the littoral zone - the degree to which erosion of dunes and } \\
\text { coastline is prevented }\end{array}$ & & $x$ & & & \\
\hline $\begin{array}{l}\text { 3. Climate change - the degree to which climate change mitigation solutions } \\
\text { are considered }\end{array}$ & & & $x$ & & \\
\hline $\begin{array}{l}\text { 4. Landscape assets (amenities) - the degree to which the waterfront } \\
\text { panorama integrates with surroundings, including how they are } \\
\text { connected /linked in space }\end{array}$ & & & $\mathrm{x}$ & & \\
\hline $\begin{array}{l}\text { 5. Location-related assets - the degree to which the seaside location and the } \\
\text { adjacency of beach are utilized and emphasized in the construction project } \\
\text { planning }\end{array}$ & & & & $x$ & \\
\hline
\end{tabular}

' The evaluation on a scale of 0 to 4 , where 0 means that the criterion is least considered, not considered or intentionally neglected during completion of the project.

Figure A2. Baltic Park Molo in Świnoujście. Building sheet. 
Construction project analysis form - Building sheet

\begin{tabular}{|c|c|c|c|c|}
\hline Building name & Field survey informa & ion & & \\
\hline Baltic Park Plaża & Date 1: August 2018 & $\begin{array}{l}\text { Date 2: : August } \\
2019\end{array}$ & & 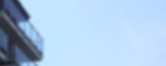 \\
\hline Location & Description & & & \\
\hline Swinoujście & $\begin{array}{l}\text { Complex of } 7 \text { apartm } \\
\text { storey, located } 30 \mathrm{~m} \\
\text { Developer: Kristense }\end{array}$ & $\begin{array}{l}\text { ent buildings, 4- } \\
\text { rom the beach. } \\
\text { Group }\end{array}$ & Source: Authe & $\Rightarrow$ \\
\hline Year(s) of construction & Study conditions & & Total points & Average score \\
\hline 2010-2015 & Sunny weather, warr & & 20 & 1.0 \\
\hline
\end{tabular}

\begin{tabular}{|c|c|c|c|c|c|}
\hline \multirow[t]{2}{*}{ Criteria } & \multicolumn{4}{|c|}{ Score for the construction project } & \multirow[t]{2}{*}{ Comments } \\
\hline & 0 & 1 & 2 & 3 & \\
\hline $\begin{array}{l}\text { 1. Scale - the degree to which the project matches with the surrounding } \\
\text { architecture }\end{array}$ & & $x$ & & & \\
\hline $\begin{array}{l}\text { 2. Colours and materials - the degree to which the project matches with } \\
\text { the surrounding architecture }\end{array}$ & & $x$ & & & \\
\hline $\begin{array}{l}\text { 3. Form - the degree to which the building matches with the surrounding } \\
\text { architecture }\end{array}$ & & $\mathrm{x}$ & & & \\
\hline $\begin{array}{l}\text { 4. Nature of the original resort - the degree to which the project is inspired } \\
\text { by traditional or regional stylistic features of the resort }\end{array}$ & $\mathrm{x}$ & & & & \\
\hline $\begin{array}{l}\text { 5. Uniqueness - the degree to which customized solutions and new } \\
\text { stylistic features are introduced }\end{array}$ & $x$ & & & & $\begin{array}{l}\text { The building complex } \\
\text { resembles a typical housing } \\
\text { estate }\end{array}$ \\
\hline
\end{tabular}

Socio-cultural factors

\begin{tabular}{|c|c|c|c|c|c|}
\hline \multirow[t]{2}{*}{ Criteria } & \multicolumn{4}{|c|}{ Score for the construction project } & \multirow[t]{2}{*}{ Comments } \\
\hline & 0 & 1 & 2 & 3 & \\
\hline 1. Social acceptance - how well local community accepts the project & & & & $\mathrm{x}$ & \\
\hline $\begin{array}{l}\text { 2. Cultural importance - the importance of the project in continuing the } \\
\text { resort's founding ideas }\end{array}$ & $\mathrm{x}$ & & & & \\
\hline $\begin{array}{l}\text { 3. Identity - the degree to which the project refers to the tradition of the } \\
\text { space and how it emphasises the local cultural identity }\end{array}$ & & $\mathrm{x}$ & & & \\
\hline $\begin{array}{l}\text { 4. Societal participation - the degree to which the opinions and needs of } \\
\text { the local community are taken into account in the construction project }\end{array}$ & & $\mathrm{x}$ & & & \\
\hline $\begin{array}{l}\text { 5. Good practice - the degree to which high-quality solutions are } \\
\text { promoted; whether the design was selected in a competition }\end{array}$ & & $\mathbf{x}$ & & & \\
\hline
\end{tabular}

\section{Functional factors}

\begin{tabular}{|c|c|c|c|c|c|}
\hline \multirow[t]{2}{*}{ Criteria } & \multicolumn{4}{|c|}{ Score for the construction project } & \multirow[t]{2}{*}{ Comments } \\
\hline & 0 & 1 & 2 & 3 & \\
\hline $\begin{array}{l}\text { 1. "Resort-creating" function-importance of the construction project for } \\
\text { the town's function as a seaside resort }\end{array}$ & $\mathrm{x}$ & & & & \\
\hline $\begin{array}{l}\text { 2. Local plan - the level of provisions implemented as part of the local } \\
\text { development plan }\end{array}$ & & & $\mathrm{x}$ & & \\
\hline $\begin{array}{l}\text { 3. Economic importance - the importance of the construction project for } \\
\text { the improvement of the town's life and economic development }\end{array}$ & & $\mathrm{x}$ & & & \\
\hline $\begin{array}{l}\text { 4. Green solutions - the degree to which green solutions are taken into } \\
\text { account }\end{array}$ & & $x$ & & & \\
\hline $\begin{array}{l}\text { 5. Accessibility - to what extent a construction project is adapted to the } \\
\text { needs of various user groups; whether the building can be utilised }\end{array}$ & & & $x$ & & \\
\hline
\end{tabular}

needs of various user groups; whether the building can be utilised

\begin{tabular}{|c|c|c|c|c|c|}
\hline \multirow[t]{2}{*}{ Criteria } & \multicolumn{4}{|c|}{ Score for the construction project } & \multirow[t]{2}{*}{ Comments } \\
\hline & 0 & 1 & 2 & 3 & \\
\hline $\begin{array}{l}\text { 1. Impact on vegetation - the degree to which the natural vegetation is } \\
\text { protected }\end{array}$ & $\mathrm{x}$ & & & & $\begin{array}{l}\text { Location in a dune - } \\
\text { negative impact on plant } \\
\text { cover }\end{array}$ \\
\hline $\begin{array}{l}\text { 2. Impact on the littoral zone - the degree to which erosion of dunes and } \\
\text { coastline is prevented }\end{array}$ & $\mathrm{x}$ & & & & \\
\hline $\begin{array}{l}\text { 3. Climate change - the degree to which climate change mitigation } \\
\text { solutions are considered }\end{array}$ & $\mathrm{x}$ & & & & \\
\hline $\begin{array}{l}\text { 4. Landscape assets (amenities) - the degree to which the waterfront } \\
\text { panorama integrates with surroundings, including how they are } \\
\text { connected/linked in space }\end{array}$ & & & $x$ & & \\
\hline $\begin{array}{l}\text { 5. Location-related assets - the degree to which the seaside location and } \\
\text { the adjacency of beach are utilized and emphasized in the construction } \\
\text { project planning }\end{array}$ & & & & $\mathrm{x}$ & $\begin{array}{l}\text { Buildings located on the } \\
\text { dune between the } \\
\text { promenade and the beach }\end{array}$ \\
\hline
\end{tabular}

'The evaluation on a scale of 0 to 4, where 0 means that the criterion is least considered, not considered or intentionally neglected during completion of the project.

Figure A3. Baltic Park Plaża in Świnoujście. Building sheet. 
Construction project analysis form - Building sheet

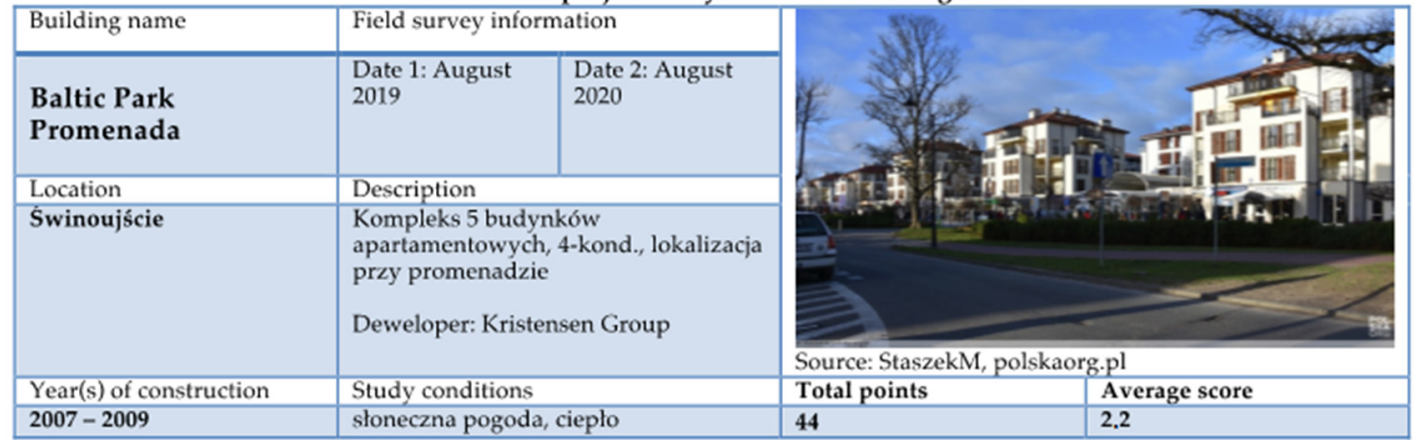

\begin{tabular}{|c|c|c|c|c|c|}
\hline \\
\hline \multirow[t]{2}{*}{ Criteria } & \multicolumn{4}{|c|}{ Score for the construction project } & \multirow[t]{2}{*}{ Comments } \\
\hline & 0 & 1 & 2 & 3 & \\
\hline $\begin{array}{l}\text { 1. Scale - the degree to which the project matches with the surrounding } \\
\text { architecture }\end{array}$ & & & & $\mathrm{x}$ & \\
\hline $\begin{array}{l}\text { 2. Colours and materials - the degree to which the project matches with } \\
\text { the surrounding architecture }\end{array}$ & & & & $\mathrm{x}$ & \\
\hline $\begin{array}{l}\text { 3. Form - the degree to which the building matches with the surrounding } \\
\text { architecture }\end{array}$ & & & & $\mathrm{x}$ & $\begin{array}{l}\text { The form of the buildings } \\
\text { resembles former } \\
\text { guesthouses }\end{array}$ \\
\hline $\begin{array}{l}\text { 4. Nature of the original resort - the degree to which the project is inspired } \\
\text { by traditional or regional stylistic features of the resort }\end{array}$ & & & & $x$ & $\begin{array}{l}\text { Features of the architecture } \\
\text { of seaside guesthouses }\end{array}$ \\
\hline $\begin{array}{l}\text { 5. Uniqueness - the degree to which customized solutions and new } \\
\text { stylistic features are introduced }\end{array}$ & & & $\mathrm{x}$ & & \\
\hline
\end{tabular}

\begin{tabular}{|c|c|c|c|c|c|}
\hline \multicolumn{6}{|l|}{ Socio-cultural factors } \\
\hline \multirow{2}{*}{ Criteria } & \multicolumn{4}{|c|}{ Score for the construction project } & \multirow[t]{2}{*}{ Comments } \\
\hline & $\mathbf{0}$ & 1 & 2 & 3 & \\
\hline 1. Social acceptance - how well local community accepts the project & & & & $\mathrm{x}$ & \\
\hline $\begin{array}{l}\text { 2. Cultural importance - the importance of the project in continuing the } \\
\text { resort's founding ideas }\end{array}$ & & & $\mathrm{x}$ & & \\
\hline $\begin{array}{l}\text { 3. Identity - the degree to which the project refers to the tradition of the } \\
\text { space and how it emphasises the local cultural identity }\end{array}$ & & & $\mathrm{x}$ & & \\
\hline $\begin{array}{l}\text { 4. Societal participation - the degree to which the opinions and needs of } \\
\text { the local community are taken into account in the construction project }\end{array}$ & & $\mathrm{x}$ & & & \\
\hline $\begin{array}{l}\text { 5. Good practice - the degree to which high-quality solutions are } \\
\text { promoted; whether the design was selected in a competition }\end{array}$ & & & $\mathrm{x}$ & & \\
\hline
\end{tabular}

\begin{tabular}{|c|c|c|c|c|c|}
\hline \multicolumn{2}{|l|}{ Functional factors } & & & & \\
\hline \multirow{2}{*}{$\begin{array}{l}\text { Functional factors } \\
\text { Criteria }\end{array}$} & & & & & \multirow[t]{2}{*}{ Comments } \\
\hline & $\mathbf{0}$ & 1 & 2 & 3 & \\
\hline $\begin{array}{l}\text { 1. "Resort-creating" function-importance of the construction project for } \\
\text { the town's function as a seaside resort }\end{array}$ & & & $\mathrm{x}$ & & \\
\hline $\begin{array}{l}\text { 2. Local plan - the level of provisions implemented as part of the local } \\
\text { development plan }\end{array}$ & & & $\mathrm{x}$ & & \\
\hline $\begin{array}{l}\text { 3. Economic importance - the importance of the construction project for } \\
\text { the improvement of the town's life and economic development }\end{array}$ & & & $\mathrm{x}$ & & \\
\hline $\begin{array}{l}\text { 4. Green solutions - the degree to which green solutions are taken into } \\
\text { account }\end{array}$ & & $\mathrm{x}$ & & & \\
\hline $\begin{array}{l}\text { 5. Accessibility - to what extent a construction project is adapted to the } \\
\text { needs of various user groups; whether the building can be utilised }\end{array}$ & & & $\mathrm{x}$ & & \\
\hline
\end{tabular}

\begin{tabular}{|c|c|c|c|c|c|}
\hline \multirow[t]{2}{*}{ Criteria } & \multicolumn{4}{|c|}{ Score for the construction project } & \multirow[t]{2}{*}{ Comments } \\
\hline & 0 & 1 & 2 & 3 & \\
\hline $\begin{array}{l}\text { 1. Impact on vegetation - the degree to which the natural vegetation is } \\
\text { protected }\end{array}$ & & & $\mathrm{x}$ & & \\
\hline $\begin{array}{l}\text { 2. Impact on the littoral zone - the degree to which erosion of dunes and } \\
\text { coastline is prevented }\end{array}$ & & & $x$ & & \\
\hline $\begin{array}{l}\text { 3. Climate change - the degree to which climate change mitigation } \\
\text { solutions are considered }\end{array}$ & & $x$ & & & \\
\hline $\begin{array}{l}\text { 4. Landscape assets (amenities) - the degree to which the waterfront } \\
\text { panorama integrates with surroundings, including how they are } \\
\text { connected/linked in space }\end{array}$ & & & & $\mathrm{x}$ & $\begin{array}{l}\text { Buildings well-integrated } \\
\text { into the surroundings }\end{array}$ \\
\hline $\begin{array}{l}\text { 5. Location-related assets - the degree to which the seaside location and } \\
\text { the adjacency of beach are utilized and emphasized in the construction } \\
\text { project planning }\end{array}$ & & & & $\mathbf{x}$ & $\begin{array}{l}\text { Location on the } \\
\text { promenade }\end{array}$ \\
\hline
\end{tabular}

\footnotetext{
'The evaluation on a scale of 0 to 4 , where 0 means that the criterion is least considered, not considered or intentionally neglected during completion of the project.
}

Figure A4. Baltic Park Promenada in Świnoujście. Building sheet. 
Construction project analysis form - Building sheet

\begin{tabular}{|l|l|l|l|}
\hline Building name & \multicolumn{2}{|l|}{ Field survey information } \\
\hline Balticus Apartments & Date 1:- & $\begin{array}{l}\text { Date 2: September } \\
2020\end{array}$ \\
\hline Location & Description & $\begin{array}{l}\text { Multi-family residential building with } \\
\text { 12 floors, retail units and a garage in } \\
\text { the building substructure. Located at } \\
\text { the promenade. The roof features an } \\
\text { open-air swimming pool, sauna and } \\
\text { an observation deck. }\end{array}$ & Source: najlepszeapartamenty.pl \\
\hline Year(s) of construction & Study conditions & Total points & $\mathbf{0 . 9 5}$ \\
\hline 2016-2019 & Sunny weather, quite warm & $\mathbf{1 9}$ & \\
\hline
\end{tabular}

Aesthetic factors
\begin{tabular}{|l|l|l|l|l|l|l|}
\hline Criteria & Score for the construction project & Comments \\
\cline { 2 - 7 } & $\mathbf{0}$ & $\mathbf{1}$ & $\mathbf{2}$ & $\mathbf{3}$ & \\
\hline $\begin{array}{l}\text { 1. Scale - the degree to which the project matches with the surrounding } \\
\text { architecture }\end{array}$ & $\mathbf{x}$ & & & & \\
\hline $\begin{array}{l}\text { 2. Colours and materials - the degree to which the project matches with } \\
\text { the surrounding architecture }\end{array}$ & & & $\mathbf{x}$ & & \\
\hline $\begin{array}{l}\text { 3. Form - the degree to which the building matches with the surrounding } \\
\text { architecture }\end{array}$ & $\mathbf{x}$ & & & & \\
\hline $\begin{array}{l}\text { 4. Nature of the original resort - the degree to which the project is inspired } \\
\text { by traditional or regional stylistic features of the resort }\end{array}$ & $\mathbf{x}$ & & & & \\
\hline $\begin{array}{l}\text { 5. Uniqueness - the degree to which customized solutions and new } \\
\text { stylistic features are introduced }\end{array}$ & & $\mathbf{x}$ & & & \\
\hline
\end{tabular}

Socio-cultural factors

\begin{tabular}{|l|l|l|l|l|l|}
\hline Criteria & \multicolumn{2}{|c|}{ Score for the construction project } & Comments \\
\cline { 4 - 5 } & $\mathbf{0}$ & $\mathbf{1}$ & $\mathbf{2}$ & $\mathbf{3}$ & \\
\hline 1. Social acceptance - how well local community accepts the project & & & $\mathbf{x}$ & & \\
\hline $\begin{array}{l}\text { 2. Cultural importance - the importance of the project in continuing the } \\
\text { resort's founding ideas }\end{array}$ & & $\mathbf{x}$ & & & \\
\hline $\begin{array}{l}\text { 3. Identity - the degree to which the project refers to the tradition of the } \\
\text { space and how it emphasises the local cultural identity }\end{array}$ & $\mathbf{x}$ & & & & \\
\hline $\begin{array}{l}\text { 4. Societal participation - the degree to which the opinions and needs of } \\
\text { the local community are taken into account in the construction project }\end{array}$ & & $\mathbf{x}$ & & & \\
\hline $\begin{array}{l}\text { 5. Good practice - the degree to which high-quality solutions are } \\
\text { promoted; whether the design was selected in a competition }\end{array}$ & & $\mathbf{x}$ & & & \\
\hline
\end{tabular}

Functional factors

Functional factors
\begin{tabular}{|l|c|c|c|c|c|}
\hline Criteria & Score for the construction project & Comments \\
\cline { 2 - 4 } & $\mathbf{0}$ & $\mathbf{1}$ & $\mathbf{2}$ & $\mathbf{3}$ & \\
\hline $\begin{array}{l}\text { 1. "Resort-creating" function - importance of the construction project for } \\
\text { the town's function as a seaside resort }\end{array}$ & & $\mathbf{x}$ & & & \\
\hline $\begin{array}{l}\text { 2. Local plan - the level of provisions implemented as part of the local } \\
\text { development plan }\end{array}$ & & $\mathbf{x}$ & & & \\
\hline $\begin{array}{l}\text { 3. Economic importance - the importance of the construction project for } \\
\text { the improvement of the town's life and economic development }\end{array}$ & & & $\mathbf{x}$ & & \\
\hline $\begin{array}{l}\text { 4. Green solutions - the degree to which green solutions are taken into } \\
\text { account }\end{array}$ & & $\mathbf{x}$ & & & \\
\hline $\begin{array}{l}\text { 5. Accessibility - to what extent a construction project is adapted to the } \\
\text { needs of various user groups; whether the building can be utilised }\end{array}$ & & $\mathbf{x}$ & & & \\
\hline
\end{tabular}

Location-related and natural factors

Location-related and natural factors
\begin{tabular}{|l|l|l|l|l|l|}
\hline Criteria & \multicolumn{1}{|c|}{ Score for the construction project } & Comments \\
\cline { 2 - 5 } & & $\mathbf{0}$ & $\mathbf{1}$ & $\mathbf{2}$ & $\mathbf{3}$ \\
\hline $\begin{array}{l}\text { 1. Impact on vegetation - the degree to which the natural vegetation is } \\
\text { protected }\end{array}$ & & $\mathbf{x}$ & & & \\
\hline $\begin{array}{l}\text { 2. Impact on the littoral zone - the degree to which erosion of dunes and } \\
\text { coastline is prevented }\end{array}$ & & $\mathbf{x}$ & & & \\
\hline $\begin{array}{l}\text { 3. Climate change - the degree to which climate change mitigation } \\
\text { solutions are considered }\end{array}$ & & $\mathbf{x}$ & & & \\
\hline $\begin{array}{l}\text { 4. Landscape assets (amenities) - the degree to which the waterfront } \\
\text { panorama integrates with surroundings, including how they are } \\
\text { connected/ linked in space }\end{array}$ & $\mathbf{x}$ & & & & \\
\hline $\begin{array}{l}\text { 5. Location-related assets - the degree to which the seaside location and } \\
\text { the adjacency of beach are utilized and emphasized in the construction } \\
\text { project planning }\end{array}$ & & & $\mathbf{x}$ & & \\
\hline
\end{tabular}

Figure A5. Balticus Apartments in Międzyzdroje. Building sheet. 
Construction project analysis form - Building sheet

\begin{tabular}{|c|c|c|c|c|}
\hline Building name & Field survey infor & nation & & \\
\hline & Date 1: May 2018 & Date 2: May 2019 & & \\
\hline Gołębiewski Hotel & & & & \\
\hline Location & Description & & & \\
\hline Pobierowo & $\begin{array}{l}\text { 11-storey hotel fac } \\
\text { conference rooms, } \\
\text { swimming pools a } \\
\text { round ice rink, tw } \\
30 \text { ha. }\end{array}$ & $\begin{array}{l}\text { lity, } 25 \mathrm{~m} \text { high, } \\
\text { sports fields, } \\
\text { 2d SPA, a year- } \\
\text { cinemas. Plot area }\end{array}$ & & \\
\hline Year(s) of construction & Stridy conditions & & Source: kamie & Aromancom \\
\hline $2017-2021$ & Sunny weather, $q$ & ite warm & 20 & $\begin{array}{l}\text { Average score } \\
1.0\end{array}$ \\
\hline
\end{tabular}

Aesthetic factors

\begin{tabular}{|c|c|c|c|c|c|}
\hline \multirow[t]{2}{*}{ Critenia } & \multicolumn{4}{|c|}{ Score for the construction project } & \multirow[t]{2}{*}{ Comments } \\
\hline & 0 & 1 & 2 & 3 & \\
\hline $\begin{array}{l}\text { 1. Scale - the degree to which the project matches with the surrounding } \\
\text { architecture }\end{array}$ & $x$ & & & & \\
\hline $\begin{array}{l}\text { 2. Colours and materials - the degree to which the project matches with } \\
\text { the surrounding ardhitecture }\end{array}$ & & $x$ & & & \\
\hline $\begin{array}{l}\text { 3. Form - the degree to which the building matches with the surrounding } \\
\text { architecture }\end{array}$ & & $x$ & & & \\
\hline $\begin{array}{l}\text { 4. Nature of the original resort - the degree to which the project is inspired } \\
\text { by traditional or regional stylistic features of the resort }\end{array}$ & $x$ & & & & $\begin{array}{l}\text { The form and scale of the } \\
\text { facility differ significantly } \\
\text { from the old resort } \\
\text { arditecture }\end{array}$ \\
\hline $\begin{array}{l}\text { 5. Uniqueness - the degree to which customized solutions and new } \\
\text { stylistic features are introduced }\end{array}$ & & $x$ & & & \\
\hline
\end{tabular}

\section{Socio-cultural factors}

\begin{tabular}{|c|c|c|c|c|c|}
\hline \multirow{2}{*}{ Criteria } & \multicolumn{4}{|c|}{ Score for the construction project } & \multirow{2}{*}{ Comments } \\
\hline & 0 & 1 & 2 & 3 & \\
\hline 1. Social acceptance - how w ell local community accepts the project & & $x$ & & & The building is controversial \\
\hline $\begin{array}{l}\text { 2. Cultural importance - the importance of the project in continuing the } \\
\text { resort's founding ideas }\end{array}$ & & $\mathrm{x}$ & & & \\
\hline $\begin{array}{l}\text { 3. Identity - the degree to which the project refers to the tradition of the } \\
\text { space and how it enphasises the local cultural identity }\end{array}$ & $x$ & & & & \\
\hline $\begin{array}{l}\text { 4. Societal participation - the degree to which the opinions and needs of } \\
\text { the local community are taken into account in the construction project }\end{array}$ & & & $\mathrm{x}$ & & \\
\hline $\begin{array}{l}\text { 5. Good practice-the degree to which high-quality solutions are } \\
\text { promoted; w hether the design was selected in a competition }\end{array}$ & $\mathrm{x}$ & & & & \\
\hline
\end{tabular}

\section{Functional factors}

\begin{tabular}{|c|c|c|c|c|c|}
\hline \multirow[t]{2}{*}{ Criteria } & \multicolumn{4}{|c|}{ Score for the construction project } & \multirow[t]{2}{*}{ Comments } \\
\hline & 0 & 1 & 2 & 3 & \\
\hline $\begin{array}{l}\text { 1. "Resort-creating" function-importance of the construction project for } \\
\text { the town's function as a seaside resort }\end{array}$ & & $x$ & & & \\
\hline $\begin{array}{l}\text { 2. Local plan - thelevel of provisions implemented as part of the local } \\
\text { development plan }\end{array}$ & & & & $x$ & \\
\hline $\begin{array}{l}\text { 3. Economic importance - the importance of the construction project for } \\
\text { the improvement of the tow n's life and economic development }\end{array}$ & & & $x$ & & \\
\hline $\begin{array}{l}\text { 4. Green solutions - the degree to which green solutions are taken into } \\
\text { account }\end{array}$ & & $x$ & & & \\
\hline $\begin{array}{l}\text { 5. Accessibility - to what extent a construction project is ad apted to the } \\
\text { needs of various user groups; w hether the building can be utilised }\end{array}$ & & & $x$ & & \\
\hline
\end{tabular}

\section{Location-related and natural factors}

\begin{tabular}{|c|c|c|c|c|c|}
\hline \multirow[t]{2}{*}{ Criteria } & \multicolumn{4}{|c|}{ Score for the construction project } & \multirow[t]{2}{*}{ Comments } \\
\hline & 0 & 1 & 2 & 3 & \\
\hline $\begin{array}{l}\text { 1. Impact on vegetation - the degree to which the natural vegetation is } \\
\text { protected }\end{array}$ & $x$ & & & & $\begin{array}{l}\text { Strong negative impact on } \\
\text { nature (massive logging) }\end{array}$ \\
\hline $\begin{array}{l}\text { 2. Impact on the littoral zone - the degree to which erosion of dunes and } \\
\text { coastline is prevented }\end{array}$ & $x$ & & & & \\
\hline $\begin{array}{l}\text { 3. Climate change - the degree to which climate change mitigation } \\
\text { solutions are considered }\end{array}$ & & $x$ & & & \\
\hline $\begin{array}{l}\text { 4. Landscape assets ( amenities) - the degree to which the waterfront } \\
\text { panorama integrates with surroundings, including how they are } \\
\text { connected/ linked in space }\end{array}$ & $x$ & & & & \\
\hline $\begin{array}{l}\text { 5. Location-related assets - the degree to which the seasidelocation and } \\
\text { the adjacency of beach are utilized and emphasized in the construction } \\
\text { project planning }\end{array}$ & & & & $\mathrm{x}$ & \\
\hline
\end{tabular}

\footnotetext{
'The evaluation on a scale of $0 \mathrm{D} 4$, w here $0 \mathrm{~m}$ eans that the criterion is leastcon sidered, notconsid ered or inten tonally nezlected du ring com plation of the pro jet
}

Figure A6. Gołębiewski Hotel in Pobierowo. Building sheet. 
Construction project analysis form - Building sheet

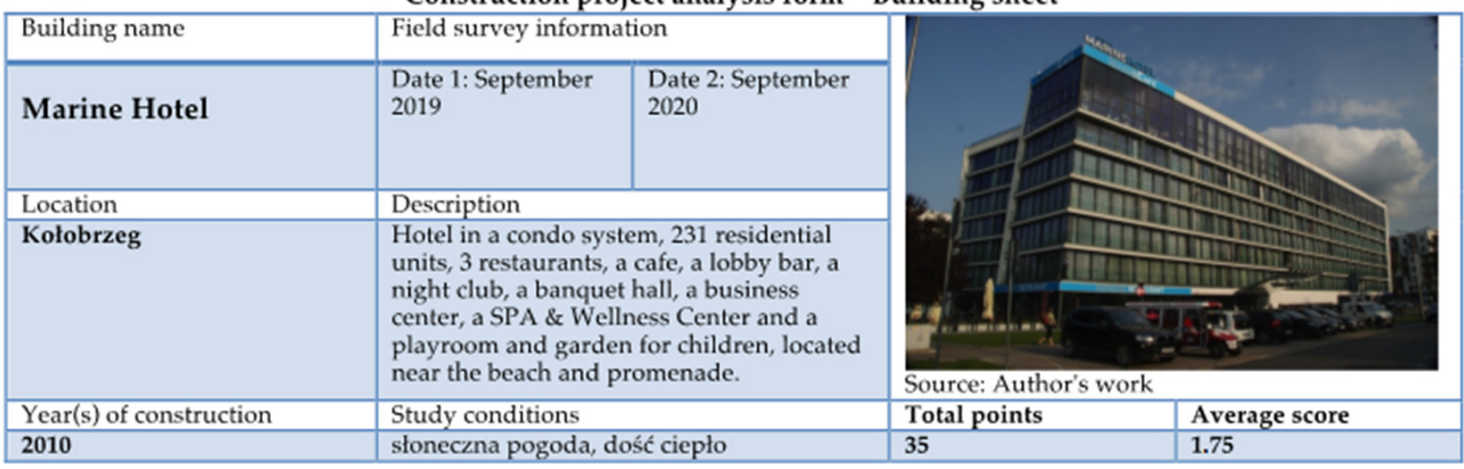

\section{Aesthetic factors}

\begin{tabular}{|c|c|c|c|c|c|}
\hline \multirow[t]{2}{*}{ Criteria } & \multicolumn{4}{|c|}{ Score for the construction project } & \multirow[t]{2}{*}{ Comments } \\
\hline & 0 & 1 & 2 & 3 & \\
\hline $\begin{array}{l}\text { 1. Scale - the degree to which the project matches with the surrounding } \\
\text { architecture }\end{array}$ & & & $\mathrm{x}$ & & \\
\hline $\begin{array}{l}\text { 2. Colours and materials - the degree to which the project matches with } \\
\text { the surrounding architecture }\end{array}$ & & & & $\mathrm{x}$ & \\
\hline $\begin{array}{l}\text { 3. Form - the degree to which the building matches with the surrounding } \\
\text { architecture }\end{array}$ & & & & $x$ & $\begin{array}{l}\text { The V-shaped building is to } \\
\text { guarantee a sea view from } \\
\text { each apartment }\end{array}$ \\
\hline $\begin{array}{l}\text { 4. Nature of the original resort - the degree to which the project is inspired } \\
\text { by traditional or regional stylistic features of the resort }\end{array}$ & & $\mathrm{x}$ & & & \\
\hline $\begin{array}{l}\text { 5. Uniqueness - the degree to which customized solutions and new } \\
\text { stylistic features are introduced }\end{array}$ & & & $x$ & & \\
\hline
\end{tabular}

\section{Czynniki społeczno-kulturowe}

\begin{tabular}{|c|c|c|c|c|c|}
\hline \multirow[t]{2}{*}{ Criteria } & \multicolumn{4}{|c|}{ Score for the construction project } & \multirow[t]{2}{*}{ Comments } \\
\hline & 0 & 1 & 2 & 3 & \\
\hline 1. Social acceptance - how well local community accepts the project & & & & $\mathrm{x}$ & \\
\hline $\begin{array}{l}\text { 2. Cultural importance - the importance of the project in continuing the } \\
\text { resort's founding ideas }\end{array}$ & & $x$ & & & \\
\hline $\begin{array}{l}\text { 3. Identity - the degree to which the project refers to the tradition of the } \\
\text { space and how it emphasises the local cultural identity }\end{array}$ & & $x$ & & & \\
\hline $\begin{array}{l}\text { 4. Societal participation - the degree to which the opinions and needs of } \\
\text { the local community are taken into account in the construction project }\end{array}$ & & $x$ & & & \\
\hline $\begin{array}{l}\text { 5. Good practice - the degree to which high-quality solutions are } \\
\text { promoted; whether the design was selected in a competition }\end{array}$ & & & $x$ & & \\
\hline
\end{tabular}

promoted; whether the design was selected in a competition

\section{Czynniki funkcjonalne}

\begin{tabular}{|c|c|c|c|c|c|}
\hline \multirow[t]{2}{*}{ Criteria } & \multicolumn{4}{|c|}{ Score for the construction project } & \multirow[t]{2}{*}{ Comments } \\
\hline & 0 & 1 & 2 & 3 & \\
\hline $\begin{array}{l}\text { 1. "Resort-creating" function - importance of the construction project for } \\
\text { the town's function as a seaside resort }\end{array}$ & & & $x$ & & \\
\hline $\begin{array}{l}\text { 2. Local plan - the level of provisions implemented as part of the local } \\
\text { development plan }\end{array}$ & & $x$ & & & \\
\hline $\begin{array}{l}\text { 3. Economic importance - the importance of the construction project for } \\
\text { the improvement of the town's life and economic development }\end{array}$ & & & $x$ & & \\
\hline $\begin{array}{l}\text { 4. Green solutions - the degree to which green solutions are taken into } \\
\text { account }\end{array}$ & & $x$ & & & \\
\hline $\begin{array}{l}\text { 5. Accessibility - to what extent a construction project is adapted to the } \\
\text { needs of various user groups; whether the building can be utilised }\end{array}$ & & & $x$ & & \\
\hline
\end{tabular}

\section{Czynniki lokalizacyjno-przyrodnicze}

\begin{tabular}{|c|c|c|c|c|c|}
\hline \multirow{2}{*}{ Criteria } & \multicolumn{4}{|c|}{ Score for the construction project } & \multirow{2}{*}{ Comments } \\
\hline & 0 & 1 & 2 & 3 & \\
\hline $\begin{array}{l}\text { 1. Impact on vegetation - the degree to which the natural vegetation is } \\
\text { protected }\end{array}$ & & $x$ & & & \\
\hline $\begin{array}{l}\text { 2. Impact on the littoral zone - the degree to which erosion of dunes and } \\
\text { coastline is prevented }\end{array}$ & & $x$ & & & \\
\hline $\begin{array}{l}\text { 3. Climate change - the degree to which climate change mitigation } \\
\text { solutions are considered }\end{array}$ & & $x$ & & & \\
\hline $\begin{array}{l}\text { 4. Landscape assets (amenities) - the degree to which the waterfront } \\
\text { panorama integrates with surroundings, including how they are } \\
\text { connected/linked in space }\end{array}$ & & & $x$ & & \\
\hline $\begin{array}{l}\text { 5. Location-related assets - the degree to which the seaside location and } \\
\text { the adjacency of beach are utilized and emphasized in the construction } \\
\text { project planning }\end{array}$ & & & & $x$ & $\begin{array}{l}\text { Located } 20 \text { meters from the } \\
\text { sea }\end{array}$ \\
\hline
\end{tabular}

\footnotetext{
'The evaluation on a scale of 0 to 4 , where 0 means that the criterion is least considered, not considered or intentionally neglected during completion of the project
}

Figure A7. Marine Hotel in Kołobrzeg. Building sheet. 
Construction project analysis form - Building sheet

\begin{tabular}{|l|l|l|l|}
\hline Building name & \multicolumn{3}{|l|}{ Field survey information } \\
\hline Rogowo Pearl & Date 1: - & $\begin{array}{l}\text { Date 2: September } \\
2020\end{array}$ \\
\hline Location & Description & \\
\hline Rogowo & $\begin{array}{l}\text { Five apartment buildings located close to } \\
\text { the lake and the sea. Extensive recreation } \\
\text { function. Relaxation zone with swimming } \\
\text { pools, playgrounds and yacht marina, pier } \\
\text { and water sports center. Inside one of the } \\
\text { buildings: swimming pool, SPA, fitness } \\
\text { room, gym, restaurant and indoor } \\
\text { playground. }\end{array}$ & Source: rogowopearl.pl \\
\hline Year(s) of construction & Study conditions & Total points & Average score \\
\hline 2018-2021 & Sunny weather, quite warm & $\mathbf{2 7}$ & $\mathbf{1 . 3 5}$ \\
\hline
\end{tabular}

\begin{tabular}{|c|c|c|c|c|c|}
\hline \\
\hline Criteria & \multicolumn{4}{|c|}{ Score for the construction project } & Comments \\
\hline 1. Scale - the degree to which the project matches with the surrounding & 0 & $\frac{1}{x}$ & 2 & 3 & \\
\hline $\begin{array}{l}\text { 2. Colours and materials - the degree to which the project matches with } \\
\text { the surrounding architecture }\end{array}$ & & & $\mathrm{x}$ & & \\
\hline $\begin{array}{l}\text { 3. Form - the degree to which the building matches with the surrounding } \\
\text { architecture }\end{array}$ & & & $\mathrm{x}$ & & $\begin{array}{l}\text { Wavy shapes inspired by the } \\
\text { sea wave }\end{array}$ \\
\hline $\begin{array}{l}\text { 4. Nature of the original resort - the degree to which the project is inspired } \\
\text { by traditional or regional stylistic features of the resort }\end{array}$ & $x$ & & & & \\
\hline $\begin{array}{l}\text { 5. Uniqueness - the degree to which customized solutions and new } \\
\text { stylistic features are introduced }\end{array}$ & & & $\mathrm{x}$ & & \\
\hline
\end{tabular}

stylistic features are introduced

\section{Socio-cultural factors}

\begin{tabular}{|c|c|c|c|c|c|}
\hline \multirow[t]{2}{*}{ Criteria } & \multicolumn{4}{|c|}{ Score for the construction project } & \multirow[t]{2}{*}{ Comments } \\
\hline & 0 & 1 & 2 & 3 & \\
\hline 1. Social acceptance - how well local community accepts the project & & & & $x$ & \\
\hline $\begin{array}{l}\text { 2. Cultural importance - the importance of the project in continuing the } \\
\text { resort's founding ideas }\end{array}$ & & $x$ & & & \\
\hline $\begin{array}{l}\text { 3. Identity - the degree to which the project refers to the tradition of the } \\
\text { space and how it emphasises the local cultural identity }\end{array}$ & $x$ & & & & \\
\hline $\begin{array}{l}\text { 4. Societal participation - the degree to which the opinions and needs of } \\
\text { the local community are taken into account in the construction project }\end{array}$ & & $x$ & & & \\
\hline $\begin{array}{l}\text { 5. Good practice - the degree to which high-quality solutions are } \\
\text { promoted; whether the design was selected in a competition }\end{array}$ & & $x$ & & & \\
\hline
\end{tabular}

promoted; whether the design was selected in a competition

\section{Functional factors}

\begin{tabular}{|c|c|c|c|c|c|}
\hline \multirow[t]{2}{*}{ Criteria } & \multicolumn{4}{|c|}{ Score for the construction project } & \multirow[t]{2}{*}{ Comments } \\
\hline & 0 & 1 & 2 & 3 & \\
\hline $\begin{array}{l}\text { 1. "Resort-creating" function - importance of the construction project for } \\
\text { the town's function as a seaside resort }\end{array}$ & & $x$ & & & \\
\hline $\begin{array}{l}\text { 2. Local plan - the level of provisions implemented as part of the local } \\
\text { development plan }\end{array}$ & & $x$ & & & \\
\hline $\begin{array}{l}\text { 3. Economic importance - the importance of the construction project for } \\
\text { the improvement of the town's life and economic development }\end{array}$ & & & $\mathrm{x}$ & & \\
\hline $\begin{array}{l}\text { 4. Green solutions - the degree to which green solutions are taken into } \\
\text { account }\end{array}$ & & $x$ & & & \\
\hline $\begin{array}{l}\text { 5. Accessibility - to what extent a construction project is adapted to the } \\
\text { needs of various user groups; whether the building can be utilised }\end{array}$ & & & $\mathrm{x}$ & & \\
\hline
\end{tabular}

\section{Location-related and natural factors}

\begin{tabular}{|c|c|c|c|c|c|}
\hline \multirow[t]{2}{*}{ Criteria } & \multicolumn{4}{|c|}{ Score for the construction project } & \multirow[t]{2}{*}{ Comments } \\
\hline & 0 & 1 & 2 & 3 & \\
\hline $\begin{array}{l}\text { 1. Impact on vegetation - the degree to which the natural vegetation is } \\
\text { protected }\end{array}$ & & $x$ & & & \\
\hline $\begin{array}{l}\text { 2. Impact on the littoral zone - the degree to which erosion of dunes and } \\
\text { coastline is prevented }\end{array}$ & & $x$ & & & \\
\hline $\begin{array}{l}\text { 3. Climate change - the degree to which climate change mitigation } \\
\text { solutions are considered }\end{array}$ & & $x$ & & & \\
\hline $\begin{array}{l}\text { 4. Landscape assets (amenities) - the degree to which the waterfront } \\
\text { panorama integrates with surroundings, including how they are } \\
\text { connected/linked in space }\end{array}$ & & $x$ & & & \\
\hline $\begin{array}{l}\text { 5. Location-related assets - the degree to which the seaside location and } \\
\text { the adjacency of beach are utilized and emphasized in the construction } \\
\text { project planning }\end{array}$ & & & & $x$ & $\begin{array}{l}\text { On the seafront, close to the } \\
\text { beach }\end{array}$ \\
\hline
\end{tabular}

\footnotetext{
'The evaluation on a scale of 0 to 4 , where 0 means that the criterion is least considered, not considered or intentionally neglected during completion of the project.
}

Figure A8. Rogowo Pearl in Rogowo. Building sheet. 
Construction project analysis form - Building sheet

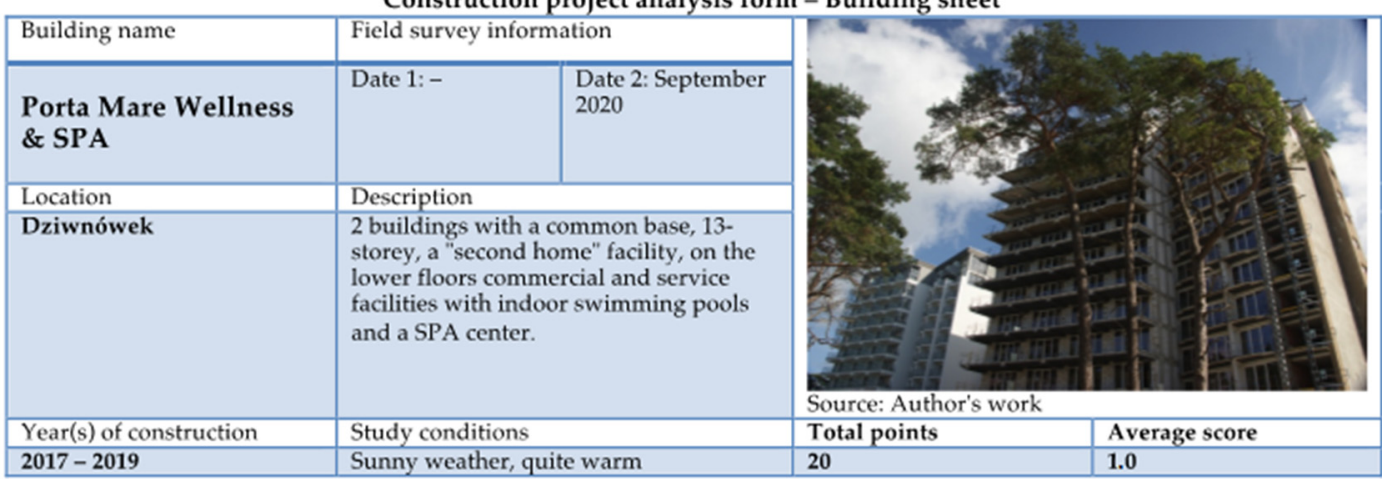

\begin{tabular}{|c|c|c|c|c|c|}
\hline \multirow{3}{*}{ Criteria } & \multirow{2}{*}{\multicolumn{4}{|c|}{ Score for the construction project }} & \multirow{3}{*}{ Comments } \\
\hline & & & & & \\
\hline & 0 & 1 & 2 & 3 & \\
\hline $\begin{array}{l}\text { 1. Scale - the degree to which the project matches with the surrounding } \\
\text { architecture }\end{array}$ & & $\mathrm{x}$ & & & \\
\hline $\begin{array}{l}\text { 2. Colours and materials - the degree to which the project matches with } \\
\text { the surrounding architecture }\end{array}$ & & & $\mathrm{x}$ & & \\
\hline $\begin{array}{l}\text { 3. Form - the degree to which the building matches with the surrounding } \\
\text { architecture }\end{array}$ & & $\mathrm{x}$ & & & \\
\hline $\begin{array}{l}\text { 4. Nature of the original resort- the degree to which the project is inspired } \\
\text { by traditional or regional stylistic features of the resort }\end{array}$ & $\mathrm{x}$ & & & & $\begin{array}{l}\text { There is no reference to the } \\
\text { features of the old resort } \\
\text { architecture }\end{array}$ \\
\hline $\begin{array}{l}\text { 5. Uniqueness - the degree to which customized solutions and new } \\
\text { stylistic features are introduced }\end{array}$ & $\mathrm{x}$ & & & & \\
\hline
\end{tabular}

Socio-cultural factors

\begin{tabular}{|l|l|l|l|l|l|l|}
\hline Criteria & \multicolumn{2}{|c|}{ Score for the construction project } & Comments \\
\cline { 2 - 5 } & & $\mathbf{0}$ & $\mathbf{1}$ & $\mathbf{2}$ & $\mathbf{3}$ & \\
\hline 1. Social acceptance - how well local community accepts the project & & $\mathbf{x}$ & & \\
\hline $\begin{array}{l}\text { 2. Cultural importance - the importance of the project in continuing the } \\
\text { resort's founding ideas }\end{array}$ & $\mathbf{x}$ & & & & \\
\hline $\begin{array}{l}\text { 3. Identity - the degree to which the project refers to the tradition of the } \\
\text { space and how it emphasises the local cultural identity }\end{array}$ & $\mathbf{x}$ & & & & \\
\hline $\begin{array}{l}\text { 4. Societal participation - the degree to which the opinions and needs of } \\
\text { the local community are taken into account in the construction project }\end{array}$ & & $\mathbf{x}$ & & & \\
\hline $\begin{array}{l}\text { 5. Good practice - the degree to which high-quality solutions are } \\
\text { promoted; whether the design was selected in a competition }\end{array}$ & & $\mathbf{x}$ & & & \\
\hline
\end{tabular}

Functional factors
\begin{tabular}{|l|l|l|l|l|l|l|}
\hline Criteria & Score for the construction project & Comments \\
\cline { 2 - 5 } & $\mathbf{0}$ & $\mathbf{1}$ & $\mathbf{2}$ & $\mathbf{3}$ & \\
\hline $\begin{array}{l}\text { 1. "Resort-creating" function - importance of the construction project for } \\
\text { the town's function as a seaside resort }\end{array}$ & & $\mathbf{x}$ & & & \\
\hline $\begin{array}{l}\text { 2. Local plan - the level of provisions implemented as part of the local } \\
\text { development plan }\end{array}$ & & $\mathbf{x}$ & & & \\
\hline $\begin{array}{l}\text { 3. Economic importance - the importance of the construction project for } \\
\text { the improvement of the town's life and economic development }\end{array}$ & & $\mathbf{x}$ & & & \\
\hline $\begin{array}{l}\text { 4. Green solutions - the degree to which green solutions are taken into } \\
\text { account }\end{array}$ & & $\mathbf{x}$ & & & \\
\hline $\begin{array}{l}\text { 5. Accessibility - to what extent a construction project is adapted to the } \\
\text { needs of various user groups; whether the building can be utilised }\end{array}$ & & & $\mathbf{x}$ & & \\
\hline
\end{tabular}

\begin{tabular}{|c|c|c|c|c|c|}
\hline \multirow{2}{*}{ Criteria } & \multicolumn{4}{|c|}{ Score for the construction project } & \multirow{2}{*}{ Comments } \\
\hline & 0 & 1 & 2 & 3 & \\
\hline $\begin{array}{l}\text { 1. Impact on vegetation - the degree to which the natural vegetation is } \\
\text { protected }\end{array}$ & & $x$ & & & \\
\hline $\begin{array}{l}\text { 2. Impact on the littoral zone - the degree to which erosion of dunes and } \\
\text { coastline is prevented }\end{array}$ & & $\mathrm{x}$ & & & \\
\hline $\begin{array}{l}\text { 3. Climate change - the degree to which climate change mitigation } \\
\text { solutions are considered }\end{array}$ & & $\mathrm{x}$ & & & \\
\hline $\begin{array}{l}\text { 4. Landscape assets (amenities) - the degree to which the waterfront } \\
\text { panorama integrates with surroundings, including how they are } \\
\text { connected/linked in space }\end{array}$ & & & $x$ & & \\
\hline $\begin{array}{l}\text { 5. Location-related assets - the degree to which the seaside location and } \\
\text { the adjacency of beach are utilized and emphasized in the construction } \\
\text { project planning }\end{array}$ & & & $\mathrm{x}$ & & \\
\hline
\end{tabular}

'The evaluation on a scale of 0 to 4 , where 0 means that the criterion is least considered, not considered or intentionally neglected during completion of the project.

Figure A9. Porta Mare Wellness \& SPA in Dziwnówek. Building sheet. 
Construction project analysis form - Building sheet

\begin{tabular}{|c|c|c|c|c|}
\hline Building name & \multicolumn{2}{|c|}{ Field survey information } & \multirow{4}{*}{\multicolumn{2}{|c|}{ Source: $\mathrm{A}$}} \\
\hline $\begin{array}{l}\text { Shellter Hotel \& } \\
\text { Apartments }\end{array}$ & Date 1:- & $\begin{array}{l}\text { Date 2: September } \\
2020\end{array}$ & & \\
\hline Location & \multirow{2}{*}{\multicolumn{2}{|c|}{$\begin{array}{l}\text { Description } \\
\text { Apartment and hotel complex including } \\
\text { apartments, a hotel with an outdoor and } \\
\text { indoor swimming pool and a spa \& } \\
\text { wellness area, cafes and restaurants, } \\
\text { walking paths and a boulevard along the } \\
\text { dunes. Project: Głebowski Studio }\end{array}$}} & & \\
\hline Rogowo & & & & \\
\hline Year(s) of construction & \multicolumn{2}{|c|}{ Study conditions } & Total points & Average score \\
\hline 2020 & \multicolumn{2}{|c|}{ Sunny weather, quite warm } & 26 & 1.3 \\
\hline
\end{tabular}

Aesthetic factors

\begin{tabular}{|c|c|c|c|c|c|}
\hline \multirow[t]{2}{*}{ Criteria } & \multicolumn{4}{|c|}{ Score for the construction project } & \multirow[t]{2}{*}{ Comments } \\
\hline & $\mathbf{0}$ & 1 & 2 & 3 & \\
\hline $\begin{array}{l}\text { 1. Scale - the degree to which the project matches with the surrounding } \\
\text { architecture }\end{array}$ & & $x$ & & & \\
\hline $\begin{array}{l}\text { 2. Colours and materials - the degree to which the project matches with } \\
\text { the surrounding architecture }\end{array}$ & & & $x$ & & \\
\hline $\begin{array}{l}\text { 3. Form - the degree to which the building matches with the surrounding } \\
\text { architecture }\end{array}$ & & $x$ & & & \\
\hline $\begin{array}{l}\text { 4. Nature of the original resort - the degree to which the project is inspired } \\
\text { by traditional or regional stylistic features of the resort }\end{array}$ & $x$ & & & & $\begin{array}{l}\text { The architectural features do } \\
\text { not correspond to the } \\
\text { original resort architecture }\end{array}$ \\
\hline $\begin{array}{l}\text { 5. Uniqueness - the degree to which customized solutions and new } \\
\text { stylistic features are introduced }\end{array}$ & & $\mathbf{x}$ & & & $\begin{array}{l}\text { The complex resembles a } \\
\text { typical modern housing } \\
\text { estate }\end{array}$ \\
\hline
\end{tabular}

Socio-cultural factors

\begin{tabular}{|c|c|c|c|c|c|}
\hline \multirow[t]{2}{*}{ Criteria } & \multicolumn{4}{|c|}{ Score for the construction project } & \multirow[t]{2}{*}{ Comments } \\
\hline & $\mathbf{0}$ & 1 & 2 & 3 & \\
\hline 1. Social acceptance - how well local community accepts the project & & & & $x$ & \\
\hline $\begin{array}{l}\text { 2. Cultural importance - the importance of the project in continuing the } \\
\text { resort's founding ideas }\end{array}$ & & $x$ & & & \\
\hline $\begin{array}{l}\text { 3. Identity - the degree to which the project refers to the tradition of the } \\
\text { space and how it emphasises the local cultural identity }\end{array}$ & $x$ & & & & \\
\hline $\begin{array}{l}\text { 4. Societal participation - the degree to which the opinions and needs of } \\
\text { the local community are taken into account in the construction project }\end{array}$ & & $x$ & & & \\
\hline $\begin{array}{l}\text { 5. Good practice - the degree to which high-quality solutions are } \\
\text { promoted; whether the design was selected in a competition }\end{array}$ & & & $x$ & & \\
\hline
\end{tabular}

\section{Functional factors}

\begin{tabular}{|c|c|c|c|c|c|}
\hline \multirow[t]{2}{*}{ Criteria } & \multicolumn{4}{|c|}{ Score for the construction project } & \multirow[t]{2}{*}{ Comments } \\
\hline & 0 & 1 & 2 & 3 & \\
\hline $\begin{array}{l}\text { 1. "Resort-creating" function-importance of the construction project for } \\
\text { the town's function as a seaside resort }\end{array}$ & & $x$ & & & \\
\hline $\begin{array}{l}\text { 2. Local plan - the level of provisions implemented as part of the local } \\
\text { development plan }\end{array}$ & & $x$ & & & \\
\hline $\begin{array}{l}\text { 3. Economic importance - the importance of the construction project for } \\
\text { the improvement of the town's life and economic development }\end{array}$ & & & $x$ & & \\
\hline $\begin{array}{l}\text { 4. Green solutions - the degree to which green solutions are taken into } \\
\text { account }\end{array}$ & & $x$ & & & \\
\hline $\begin{array}{l}\text { 5. Accessibility - to what extent a construction project is adapted to the } \\
\text { needs of various user groups; whether the building can be utilised }\end{array}$ & & & $x$ & & \\
\hline
\end{tabular}

\section{Location-related and natural factors}

\begin{tabular}{|c|c|c|c|c|c|}
\hline \multirow[t]{2}{*}{ Criteria } & \multicolumn{4}{|c|}{ Score for the construction project } & \multirow[t]{2}{*}{ Comments } \\
\hline & 0 & 1 & 2 & 3 & \\
\hline $\begin{array}{l}\text { 1. Impact on vegetation - the degree to which the natural vegetation is } \\
\text { protected }\end{array}$ & & $x$ & & & \\
\hline $\begin{array}{l}\text { 2. Impact on the littoral zone - the degree to which erosion of dunes and } \\
\text { coastline is prevented }\end{array}$ & $x$ & & & & $\begin{array}{l}\text { Location in the dunes } \\
\text { (strong transformations) }\end{array}$ \\
\hline $\begin{array}{l}\text { 3. Climate change - the degree to which climate change mitigation } \\
\text { solutions are considered }\end{array}$ & & $x$ & & & \\
\hline $\begin{array}{l}\text { 4. Landscape assets (amenities) - the degree to which the waterfront } \\
\text { panorama integrates with surroundings, including how they are } \\
\text { connected/linked in space }\end{array}$ & & & $x$ & & \\
\hline $\begin{array}{l}\text { 5. Location-related assets - the degree to which the seaside location and } \\
\text { the adjacency of beach are utilized and emphasized in the construction } \\
\text { project planning }\end{array}$ & & & & $x$ & \\
\hline
\end{tabular}

Figure A10. Shelter Hotel \& Apartments in Rogowo. Building sheet. 
Construction project analysis form - Building sheet

\begin{tabular}{|l|l|l|l|}
\hline Building name & \multicolumn{3}{|l|}{ Field survey information } \\
\hline Wave Apartments & $\begin{array}{l}\text { Date 1: September } \\
2019\end{array}$ & $\begin{array}{l}\text { Date 2: September } \\
2020\end{array}$ \\
\hline Location & Description & $\begin{array}{l}\text { Five apartment buildings, 11 floors, } \\
\text { residential function (390 apartments), } \\
\text { recreational, sports and commercial and } \\
\text { service functions (SPA, Wellness zone, } \\
\text { heated swimming pool, fit \& gym are } \\
\text { planned. } \\
\text { Design: MODOarchitektura }\end{array}$ & Source:archinea.pl \\
\hline Year(s) of construction & Study conditions & Total points & Average score \\
\hline 2018-2021 & Sunny weather, quite warm & $\mathbf{2 4}$ & $\mathbf{1 . 2}$ \\
\hline
\end{tabular}

Aesthetic factors

\begin{tabular}{|l|l|l|l|l|l|}
\hline Criteria & \multicolumn{2}{|c|}{ Score for the construction project } & Comments \\
\cline { 2 - 5 } & $\mathbf{0}$ & $\mathbf{1}$ & $\mathbf{2}$ & $\mathbf{3}$ & \\
\hline $\begin{array}{l}\text { 1. Scale - the degree to which the project matches with the surrounding } \\
\text { architecture }\end{array}$ & $\mathbf{x}$ & & & & \\
\hline $\begin{array}{l}\text { 2. Colours and materials - the degree to which the project matches with } \\
\text { the surrounding architecture }\end{array}$ & & & $\mathbf{x}$ & & \\
\hline $\begin{array}{l}\text { 3. Form - the degree to which the building matches with the surrounding } \\
\text { architecture }\end{array}$ & & & $\mathbf{x}$ & & $\begin{array}{l}\text { Design inspired by the } \\
\text { coastal breeze and sea wave }\end{array}$ \\
\hline $\begin{array}{l}\text { 4. Nature of the original resort - the degree to which the project is inspired } \\
\text { by traditional or regional stylistic features of the resort }\end{array}$ & $\mathbf{x}$ & & & & \\
\hline $\begin{array}{l}\text { 5. Uniqueness - the degree to which customized solutions and new } \\
\text { stylistic features are introduced }\end{array}$ & & & & $\mathbf{x}$ & \\
\hline
\end{tabular}

\section{Socio-cultural factors}

\begin{tabular}{|c|c|c|c|c|c|}
\hline \multirow[t]{2}{*}{ Criteria } & \multicolumn{4}{|c|}{ Score for the construction project } & \multirow[t]{2}{*}{ Comments } \\
\hline & 0 & 1 & 2 & 3 & \\
\hline 1. Social acceptance - how well local community accepts the project & & $x$ & & & \\
\hline $\begin{array}{l}\text { 2. Cultural importance - the importance of the project in continuing the } \\
\text { resort's founding ideas }\end{array}$ & & $\mathbf{x}$ & & & \\
\hline $\begin{array}{l}\text { 3. Identity - the degree to which the project refers to the tradition of the } \\
\text { space and how it emphasises the local cultural identity }\end{array}$ & $x$ & & & & \\
\hline $\begin{array}{l}\text { 4. Societal participation - the degree to which the opinions and needs of } \\
\text { the local community are taken into account in the construction project }\end{array}$ & & $\mathrm{x}$ & & & \\
\hline $\begin{array}{l}\text { 5. Good practice - the degree to which high-quality solutions are } \\
\text { promoted; whether the design was selected in a competition }\end{array}$ & & & $\mathrm{x}$ & & \\
\hline
\end{tabular}

\section{Functional factors}

\begin{tabular}{|l|l|l|l|l|l|}
\hline Criteria & \multicolumn{2}{|c|}{ Score for the construction project } & Comments \\
\cline { 2 - 4 } & $\mathbf{0}$ & $\mathbf{1}$ & $\mathbf{2}$ & $\mathbf{3}$ & \\
\hline $\begin{array}{l}\text { 1. "Resort-creating" function - importance of the construction project for } \\
\text { the town's function as a seaside resort }\end{array}$ & & $\mathbf{x}$ & & & \\
\hline $\begin{array}{l}\text { 2. Local plan - the level of provisions implemented as part of the local } \\
\text { development plan }\end{array}$ & $\mathbf{x}$ & & & & $\begin{array}{l}\text { No spatial development } \\
\text { plan, revitalization plan for } \\
\text { the village }\end{array}$ \\
\hline $\begin{array}{l}\text { 3. Economic importance - the importance of the construction project for } \\
\text { the improvement of the town's life and economic development }\end{array}$ & & & $\mathbf{x}$ & & \\
\hline $\begin{array}{l}\text { 4. Green solutions - the degree to which green solutions are taken into } \\
\text { account }\end{array}$ & & $\mathbf{x}$ & & & \\
\hline $\begin{array}{l}\text { 5. Accessibility - to what extent a construction project is adapted to the } \\
\text { needs of various user groups; whether the building can be utilised }\end{array}$ & & $\mathbf{x}$ & & & \\
\hline
\end{tabular}

needs of various user groups; whether the building can be utilised

\section{Location-related and natural factors}

\begin{tabular}{|c|c|c|c|c|c|}
\hline \multirow[t]{2}{*}{ Criteria } & \multicolumn{4}{|c|}{ Score for the construction project } & \multirow[t]{2}{*}{ Comments } \\
\hline & 0 & 1 & 2 & 3 & \\
\hline $\begin{array}{l}\text { 1. Impact on vegetation - the degree to which the natural vegetation is } \\
\text { protected }\end{array}$ & & $x$ & & & \\
\hline $\begin{array}{l}\text { 2. Impact on the littoral zone - the degree to which erosion of dunes and } \\
\text { coastline is prevented }\end{array}$ & & $\mathrm{x}$ & & & \\
\hline $\begin{array}{l}\text { 3. Climate change - the degree to which climate change mitigation } \\
\text { solutions are considered }\end{array}$ & & $x$ & & & \\
\hline $\begin{array}{l}\text { 4. Landscape assets (amenities) - the degree to which the waterfront } \\
\text { panorama integrates with surroundings, including how they are } \\
\text { connected/linked in space }\end{array}$ & & $x$ & & & \\
\hline $\begin{array}{l}\text { 5. Location-related assets - the degree to which the seaside location and } \\
\text { the adjacency of beach are utilized and emphasized in the construction } \\
\text { project planning }\end{array}$ & & & & $x$ & $\begin{array}{l}\text { On the seafront, only } 60 \mathrm{~m} \\
\text { from the beach }\end{array}$ \\
\hline
\end{tabular}

\footnotetext{
'The evaluation on a scale of 0 to 4 , where 0 means that the criterion is least considered, not considered or intentionally neglected during completion of the project.
}

Figure A11. Wave Apartments in Międzyzdroje. Building sheet. 


\section{References}

1. Bal, W.; Czalczynska-Podolska, M. The stages of the cultural landscape transformation of seaside resorts in Poland against the background of the evolving nature of tourism. Land 2020, 9, 55. [CrossRef]

2. Bal, W. Contemporary trends and transformations in the public space of seaside resorts. In Social Sciences $\mathcal{E}$ Arts, Proceedings of the 5th International Multidisciplinary Scientific Conference on Social Sciences and Arts SGEM 2018, Albena, Bulgaria, 26 August-1 September 2018; STEF92 Technology Ltd.: Albena, Bulgaria, 2018; Volume 5, pp. 133-140.

3. Bal, W.; Czalczynska-Podolska, M. The integration of architecture and landscape as a model factor for assessment of the cultural landscape. In Social Sciences \& Arts, Proceedings of the 5th International Multidisciplinary Scientific Conference on Social Sciences and Arts SGEM 2018, Albena, Bulgaria, 26 August-1 September 2018; STEF92 Technology Ltd.: Albena, Bulgaria, 2018; Volume 5, pp. 621-628. [CrossRef]

4. Crang, M. Cultural Geographies of Tourism. In A Companion to Tourism; Lew, A., Hall, C.M., Williams, A.M., Eds.; Blackwell Publishing Ltd.: Oxford, UK, 2004; pp. 74-84.

5. Council of Europe. European Landscape Convention. Available online: https://www.eea.europa.eu/policy-documents/ european-landscape-convention (accessed on 10 September 2020).

6. Coccossis, H.; Tsartas, P. Tourism and the Environment. In Tourism Recreation Series; Kritiki: Athens, Greece, 2001.

7. Williams, A.M.; Hall, C.M. Tourism and migration: New relationships between production and consumption. Tour. Geogr. 2002, 2, 5-27. [CrossRef]

8. Roe, D.; Leader-Williams, N.; Dalal-Clayton, B. Take Only Photographs, Leave Only Footprints. In The Environmental Impacts of Wildlife Tourism; The International Institute for Environment and Development: London, UK, 1997.

9. Jafari, J. Bridging out, nesting afield: Powering a new platform. J. Tour. Stud. 2005, 16, 1-5.

10. Jafari, J. Entry into a new field of study: Leaving a footprint. In The Study of Tourism: Anthropological and Sociological Beginnings; Nash, D., Ed.; Elsevier: Oxford, UK, 2007; pp. 108-121.

11. Hudson, J.; Lowe, S. Understanding the Policy Process. In Analysing Welfare Policy and Practice, 2nd ed.; The Policy Press: Bristol, UK, 2004.

12. Crouch, D. Tourism, performance and the everyday. Leis. Stud. 2011, 30, 378-380. [CrossRef]

13. Williams, S.W. Tourism Geography: A New Synthesis, 2nd ed.; Routledge: New York, NY, USA, 2009.

14. Postma, A.; Schilder, A.K. Critical Impacts of tourism; the case of Schiermonnikoog. In Social and Cultural Change: Making Space(s) for Leisure and Tourism, Leisure Studies Association Publication; Casado-Diaz, M., Everett, S., Wilson, J., Eds.; University of Brighton: Eastborne, UK, 2001; Volume 98, pp. 131-150.

15. Stoffelen, A.; Vanneste, D. An integrative geotourism approach: Bridging conflicts in tourism landscape research. Tour. Geogr. 2015, 17, 544-560. [CrossRef]

16. Urry, J. The Tourist Gaze; SAGE Publications Ltd.: London, UK, 2002.

17. Carneiro, M.J.; Lima, J.; Lavrador Silva, A. Landscape and the rural tourism experience: Identifying key elements, addressing potential, and implications for the future. J. Sustain. Tour. 2015, 23, 1217-1235. [CrossRef]

18. Munt, I. The "Other" Postmodern Tourism: Culture Travel and the New Middle Classes. Theory Cult. Soc. 1994, 11, 101-123. [CrossRef]

19. MacCannell, D. Remarks on the Commodification of Cultures. In Host and Guests Re-Visited: Tourism Issues of the 21st Century; Smith, V.L., Brent, M., Eds.; Cognizant Communication Corporation: New York, NY, USA, 2001.

20. Warnken, J.; Russel, R.; Faulkner, B. Condominium developments in maturing destinations: Potentials and problems of long-term sustainability. Tour. Manag. 2003, 24, 155-168. [CrossRef]

21. Pitkänen, K. Second-home Landscape: The Meaning(s) of Landscape for Second-home Tourism in Finnish Lakeland. Tour. Geogr. 2008, 10, 169-192. [CrossRef]

22. Antrop, M. Landscape Change: Plan or Chaos? Landsc. Urban Plan. 1998, 41, 155-161. [CrossRef]

23. Terkenli, T.S. Landscapes of tourism: Towards a glob-al cultural economy of space? Tour. Geogr. 2002, 4, 227-254. [CrossRef]

24. Ritzer, G. The McDonaldization of Society: An Investigation into the Changing Character of Contemporary Social Life; Pine Forge Press: Thousand Oaks, CA, USA, 1993.

25. Liszewski, S. Przestrzeń turystyczna i osadnictwo turystyczne. In Kompendium Wiedzy o Turystyce; Gołembski, G., Ed.; Wyd. Naukowe PWN: Warszawa, Poland, 2002; pp. 77-109.

26. Relph, E. Place and Placelessness; Pion: London, UK, 1976.

27. Leyva, C.; Espejel, I.; Escfet, A.; Bullock, S.H. Coastal Landscape Fragmentation by Tourism Development: Impacts and Conservation Alternatives. Natl. Areas J. 2006, 26, 117-125. [CrossRef]

28. Terkenli, T.S. Tourism and Landscape. In A Companion to Tourism; Lew, A.A., Hall, C.M., Williams, A.M., Eds.; Blackwell Publishing: Oxford, UK, 2004; pp. 282-293.

29. Morgan, N. Problematizing Place Promotion. In A Companion to Tourism; Lew, A.A., Hall, C.M., Williams, A.M., Eds.; Blackwell Publishing: Oxford, UK, 2004; pp. 171-183.

30. Tuğba, K. Role of Ecotourism in Sustainable Development. In Advances in Landscape Architecture; Özyavuz, M., Ed.; IntechOpen: Rijeka, Croatia, 2013; Available online: https://www.intechopen.com/books/advances-in-landscape-architecture/role-ofecotourism-in-sustainable-development (accessed on 2 October 2020).

31. Mill, R.C.; Morrison, A.M. The Tourism System, 4th ed.; Kendall/Hunt Publishing Company: Dubuque, IA, USA, 2002. 
32. World Tourism Organisation. Sustainable Development of Tourism. Concepts and Definitions. 2004. Available online: www. world-tourism.org/sustainable/top/concepts.html (accessed on 2 October 2020).

33. Daniel, T.C.; Boster, R.S. Measuring Landscape Esthetics: The Scenic Beauty Estimation Method. USDA Forest Service. 1976. Available online: https:/ / www.fs.fed.us/rm/pubs_rm/rm_rp167.pdf (accessed on 2 October 2020).

34. Visual Resource Management Program. Bureau of Land Management; US Department of Interior: Washington, DC, USA, 1980.

35. Wejchert, K. Elementy Kompozycji Urbanistycznej; Arkady: Warszawa, Poland, 1974.

36. Polat, A.T. Visual Quality Assessment in Landscape Architecture. In Proceedings of the 9th International Academic Conference, Florence, Italy, 16-19 September 2015; International Institute of Social and Economic Sciences: London, UK, 2015; pp.637-648. Available online: https://www.researchgate.net/publication/282665755_Visual_Quality_Assessment_in_ Landscape_Architecture (accessed on 15 October 2020).

37. Clay, G.; Daniel, T. Scenic Landscape Assesssment: The Effects of Land Management Jurisdiction On Public Perception Of Scenic Beauty. Landsc. Urban Plan. 2000, 49, 1-13. [CrossRef]

38. Ak, M.K. Visual Quality Assessment Methods in Landscape Architecture Studies. In Advances in Landscape Architecture; Özyavuz, M., Ed.; IntechOpen: Rijeka, Croatia, 2013; Available online: https://www.intechopen.com/books/advances-in-landscapearchitecture/visual-quality-assessment-methods-in-landscape-architecture-studies (accessed on 15 October 2020).

39. Lothian, A. Measuring and Mapping Landscape Quality Using the Community Preferences Method. In Proceedings of the New Zealand Planning Institute Annual Conference, Blenheim, UK, 1-4 May 2012; Available online: https:/ / scenicsolutions.world/ wp-content/uploads/2017/08/measuring-and-mapping-landscape-quality-using-the-community-preferences-method.pdf (accessed on 15 October 2020).

40. Kaplan, R.; Kaplan, S. Experience of Nature; Cambridge University Press: New York, NY, USA, 1989.

41. Nasar, J.L. The Evaluative Image of the City; Sage Publications: Thousand Oaks, CA, USA, 1998.

42. Keleş, E.; Atik, D.; Bayrak, G. Visual Landscape Quality Assessment in Historical Cultural Landscape Areas. Eur. J. Sustain. Dev. 2018, 7, 287-300. [CrossRef]

43. Myga-Piątek, U. Kryteria i metody oceny krajobrazu kulturowego w procesie planowania przestrzennego na t l e obowiązujacych procedur prawnych (Criteria and methods of assessment of cultural landscape in the process of spatial planning against the existing legal procedures). In Waloryzacja Środowiska Przyrodniczego w Planowaniu Przestrzennym (Environmental Assessment in Physical Planning); Kistowski, M., Korwel-Lejkowska, B., Eds.; Uniwersytet Gdański: Gdańsk, Poland, 2007; pp. 101-110.

44. Żarska, B. Ochrona Krajobrazu; SGGW: Warszawa, Poland, 2012.

45. Natural England. An Approach to Seascape Character Assessment; England Commissioned Report NECR105; Natural England: York, UK, 2012. Available online: https://assets.publishing.service.gov.uk/government/uploads/system/uploads/attachment_data/ file/396177/seascape-character-assessment.pdf (accessed on 15 October 2020).

46. Bal, W. Specyfika krajobrazu kulturowego kurortów nadmorskich. Próba określenia tożsamości kulturowej regionu nadmorskiego w kontekście postępującej degradacji krajobrazu kulturowego kurortów nadmorskich na Pomorzu Zachodnim Specificity of the cultural landscape of seaside resorts. In An Attempt to Determine the Cultural Identity of a Coastal Region in the Context of the Progressive Degradation of the Cultural Landscape of Seaside Resorts in Western Pomerania; Wyd. HOGBEN: Szczecin, Poland, 2009.

47. Gilbert, E.W. The growth of inland and seaside health resorts in England. Scott. Geogr. Mag. 1939, 55, 16-35.

48. Christaller, W. Some considerations of tourism location in Europe. Pap. Reg. Sci. Assoc. 1963, 12, 95-105.

49. Cohen, E. Towards a sociology of international tourism. Soc. Res. 1972, 39, 164-182.

50. Butler, R.W. The concept of the tourist area life-cycle of evolution: Implications for management of resources. Can. Geogr. 1980, 24, 5-12. [CrossRef]

51. Smith, R.A. Beach resort evolution: Implications for planning. Ann. Tour. Res. 1992, 2, 304-322. [CrossRef]

52. Smith, R. Review of Integrated Beach Resort Development in Southeast Asia. Land Use Policy 1992, 9, 209-217. [CrossRef]

53. Young, B. Touristization of Traditional Maltese Fishing-farming Villages. Tour. Manag. 1983, 4, 35-41. [CrossRef]

54. Bianchi, R. Tourism Development and Resort Dynamics: An Alternative Approach. In Progress in Tourism, Recreation and Hospitality Management; Cooper, C.P., Lockwood, A., Eds.; Belhaven: London, UK, 1994; Volume 5, pp. 181-193.

55. Hall, C. Trends in ocean and coastal tourism: The end of the last frontier? Ocean Coast. Manag. 2001, 44, 601-618. [CrossRef]

56. Butowski, L. Maritime Tourism Space. Turyzm 2014, 24, 57-64. [CrossRef]

57. Butowski, L. Model of sustainable tourism. Teoretical and empirical approach. Folia Turistica. 2014, 33, 9-33.

58. Gormsen, E. The spatio-temporal development of international tourism: Attempt at a centre-periphery model. In La Consommation D'Espace par le Tourisme et sa Preservation; Intenational Geographical Union, Ed.; CHET: Aix-en-Provence, France, 1981; pp. 150-170.

59. Smith, R.A. Beach resorts: A model of development evolution. Landsc. Urban Plan. 1991, 21, 189-210. [CrossRef]

60. Myga-Piątek, U. Krajobraz kulturowy jako walor i produkt turystyczny-Problemy oceny i ochrony. In Krajobraz KulturowyCechy, Walory, Ochrona. Problemy Ekologii Krajobrazu; Wołoszyn, W., Ed.; UMCS: Lublin, Poland, 2006; Volume 18, pp. $201-212$.

61. Larsen, K. The Other Side of "Nature". In Producing Nature and Poverty in Africa; Broch-Due, V., Schroeder, R.A., Eds.; Nordiska Afrikainstitutet: Uppsala, Sweden, 2000.

62. Pielesiak, I. Dezintegracja przestrzeni łodzi w świetle badań społecznych. Stud. Miejskie 2016, 21, 53-65.

63. Merida, R.M.; Lobon, M.R. Landscape Integration and Its Foundations. Method of Application for Remote Buildings in Rural Areas. Assoc. Geogr. Newslett. 2011, 56, 455-461. 
64. Komarova, M. Integration of the historic urban landscape with contemporary architecture. In Resilient Landscape for Cities of the Future; Uniscape: Ascoli Piceno, Italy, 2015; pp. 292-294.

65. Pearce, D. Tourist Development, 2nd ed.; Longman Scientific \& Technical: New York, NY, USA, 1989.

66. Bal, W. Pluralistic trends in development of seaside landscape of Western Pomerania. Files Urban Plan. Archit. Comm. Branch PAS Krakow 2018, 46, 483-495. 